\title{
Can Plant- and Cell-Based Seafood Improve Human and Planetary Health? \\ An examination of the environmental, social and economic costs and benefits of seafood alternatives
}

27 April 2020

Prepared by Meghan Jeans on behalf of the Wildlife Conservation Society's New York Aquarium

The findings and conclusions stated in this white paper, commissioned by the Wildlife Conservation Society (WCS), are those of Meghan Jeans, and not necessarily WCS. WCS does not recommend or endorse any plant-based or cell-based seafood or other commercial products mentioned in the white paper. 


\section{Table of Contents}

Executive Summary

$\begin{array}{lll}1.0 & \text { Introduction } & 1\end{array}$

2.0 Conventional Seafood: Fisheries and Aquaculture 2

2.1 Seafood market and industry trends $\quad 2$

2.1.1 Global seafood supply and demand

2.1.2 United States seafood supply and demand

2.2 Environmental costs and benefits of fisheries and aquaculture $\mathbf{5}$
2.2.1 Wild capture fisheries
2.2.2 Aquaculture

2.3 Socio-economic impacts of fisheries and aquaculture
2.3.1 Economic and food security
2.3.2 Unfair and exploitative labor practices
2.3.3 Illegal, unreported and unregulated fishing

2.4 Seafood nutrition and human health

2.4.1 Health and nutritional benefits

2.4.2 Health and nutritional risks

3.0 Plant-Based Seafood 17

3.1 Plant-based seafood market and industry trends

3.2 Environmental costs and benefits of plant-based seafood 18

3.2.1 Plant agriculture

3.2.2 Seaweed and algae production

3.3 Socio-economic costs and benefits of plant-based seafood 26

3.3.1 Economic and food security

3.3.2 Unfair and exploitative labor practices

3.4 Nutrition and human health implications of plant-based seafood 27

3.4.1 Health and nutritional benefits

3.4.2 Health and nutritional risks

4.0 Cell-Based Seafood 30

4.1 Cell-based seafood market and industry trends 30

4.2 Environmental costs and benefits of cell-based seafood 32

4.3 Socio-economic costs and benefits of cell-based seafood 33

4.3.1 Socio-economic benefits

4.3.2 Socio-economic costs

4.4 Nutrition and human health implications of cell-based seafood 34

4.4.1 Health and nutritional benefits

4.4.2 Health and nutritional risks

5.0 Governance Opportunities and Obstacles 35

$\begin{array}{lll}\mathbf{5 . 1} & \text { Federal agency jurisdiction } & 35\end{array}$

5.2 Federal and state labeling laws $\quad 35$

5.3 Government funding and support 36

6.0 Research and Resource Needs and Opportunities 37

$\begin{array}{lll}6.1 & \text { Plant-based and cell-based seafood } & 38\end{array}$

$\begin{array}{lll}6.2 & \text { Plant-based seafood } & 39\end{array}$

6.3 Cell-based seafood 41

7.0 Conclusion 42

Appendix: Workshop Agenda 43 


\section{Executive Summary}

As the global human population grows and average lifespan increases, so too does the demand for seafood. However, the capacity of our oceans and coasts to feed a growing population is limited. While there has been incremental progress to improve the sustainability and social responsibility of fisheries and aquaculture, the growing pressure on the natural and human resources required to produce the global seafood supply is rapidly undermining environmental sustainability, human health and economic and food security.

Advances in bioengineering and food innovation coupled with a growing appetite for affordable, healthy, humane, sustainable and socially responsible seafood have inspired the emergence of plant- and cell-based seafood alternatives. But how do these alternatives compare to traditional wild capture and farmed seafood? What promises do they offer in terms of promoting food security, socio-economic development and human and planetary health? Similarly, what are the potential costs of diversifying our dinner plate in this way? Are these seafood alternatives a passing trend or part of a larger shift in our food system?

The mission of the Wildlife Conservation Society (WCS) is to save wildlife and wild places worldwide through science, conservation action, education and inspiring people to value nature. WCS's New York Aquarium, which works to advance seafood sustainability and educate its visiting public about the costs and benefits of various forms of seafood production, has been wrestling with these questions. To examine these issues more closely and engage others in this dialogue, the Aquarium convened a one-day workshop on March 2, 2020 in New York. The workshop, which included a diverse cross-section of stakeholders representing the seafood industry, plant- and cell- based seafood producers, academia, retailers, chefs and restaurants, and NGOs, was designed to facilitate learning and networking and stimulate further inquiry and collaboration around these emerging industries.

The following white paper, which is based on information and insight gleaned from the workshop as well expert interviews and a literature review, provides a preliminary examination of market trends and the potential environmental, socio-economic, and human health costs and benefits of plant- and cell-based seafood relative to wild capture fisheries and aquaculture. As plant- and cell-based seafood alternatives are still in their infancy, there remain a lot of untested assumptions, unanswered questions and opportunities for further research, inquiry and collaboration. Indeed, there are research, funding, governance and capacity gaps that present obstacles to understanding, comparing, developing and scaling plant- and cell-based seafood alternatives. Still, diversification of our food system to include new modes of sustainable, healthy and socially responsible seafood production is needed to mitigate risk and to feed a growing global population. Whether seafood alternatives can meet this need, and whether they will supplement or displace conventional seafood products in the marketplace, will be a function of many factors, not the least of which is product alignment with consumer values and expectations around taste and texture, cost parity, and accessibility.

To close our knowledge gaps and advance solutions that address some of the social, environmental and human health and nutrition challenges associated with conventional seafood production requires a multi-stakeholder commitment to collaboration, research and information-sharing, financing, capacity-building, and governance reform.

\subsection{Introduction}

To develop a better understanding of the environmental, socio-economic, and human health impacts of plantand cell-based seafood alternatives relative to their conventional seafood counterparts and identify gaps in existing data, capacity and knowledge, the New York Aquarium has prepared the following white paper informed by discussions at a March 2020 multi-stakeholder workshop, expert interviews, and a desktop review of the plant- and cell-based seafood literature and landscape. 
Globally, the seafood industry has played a critical role contributing to the economic and food security of millions while shaping the history and culture of many regions, but increasingly the growth in the seafood sector is coming at the expense of environmental sustainability and social equity. The United Nations Food and Agriculture Organization (FAO) recognizes that the seafood sector, both capture fisheries and aquaculture, is facing major challenges, ranging from weak governance and poor management to destructive fishing practices and pervasive illegal, unreported and unregulated (IUU) fishing. ${ }^{2}$ While there has been incremental progress focused on improving management, transparency and accountability in the seafood sector, ensuring the long term sustainability of the industry requires a closer look at the economic, social and ecological trade-offs associated with conventional seafood.

\subsection{Seafood market and industry trends}

\subsubsection{Global seafood supply and demand}

The global demand for seafood continues to increase as the human population grows. Over the past 60 years, annual global consumption of seafood products per capita has more than doubled from almost $10 \mathrm{~kg}$ in $1960^{3}$ to $20.5 \mathrm{~kg}$ in 2019. ${ }^{4}$ To meet this growing demand, the total global catch of marine capture fisheries has increased from approximately 20 million tons in $1950^{5}$ to an estimated 94.5 million tons in $2018 .{ }^{6}$ (Figure 1). Notably, more than a third of global marine fishery landings are used for non-food purposes (animal feed, bio-fuel, etc.), although the proportion of landings for non-food purposes is decreasing over time. ${ }^{7}$ The UN FAO predicts that the 2019 production levels of wild capture fisheries will decrease by some 3.4 million tons, but will be offset by a 3.9 million ton increase in aquaculture production (Table 1$)^{8}$

Figure 1. World Capture Fisheries and Aquaculture Production ${ }^{9}$

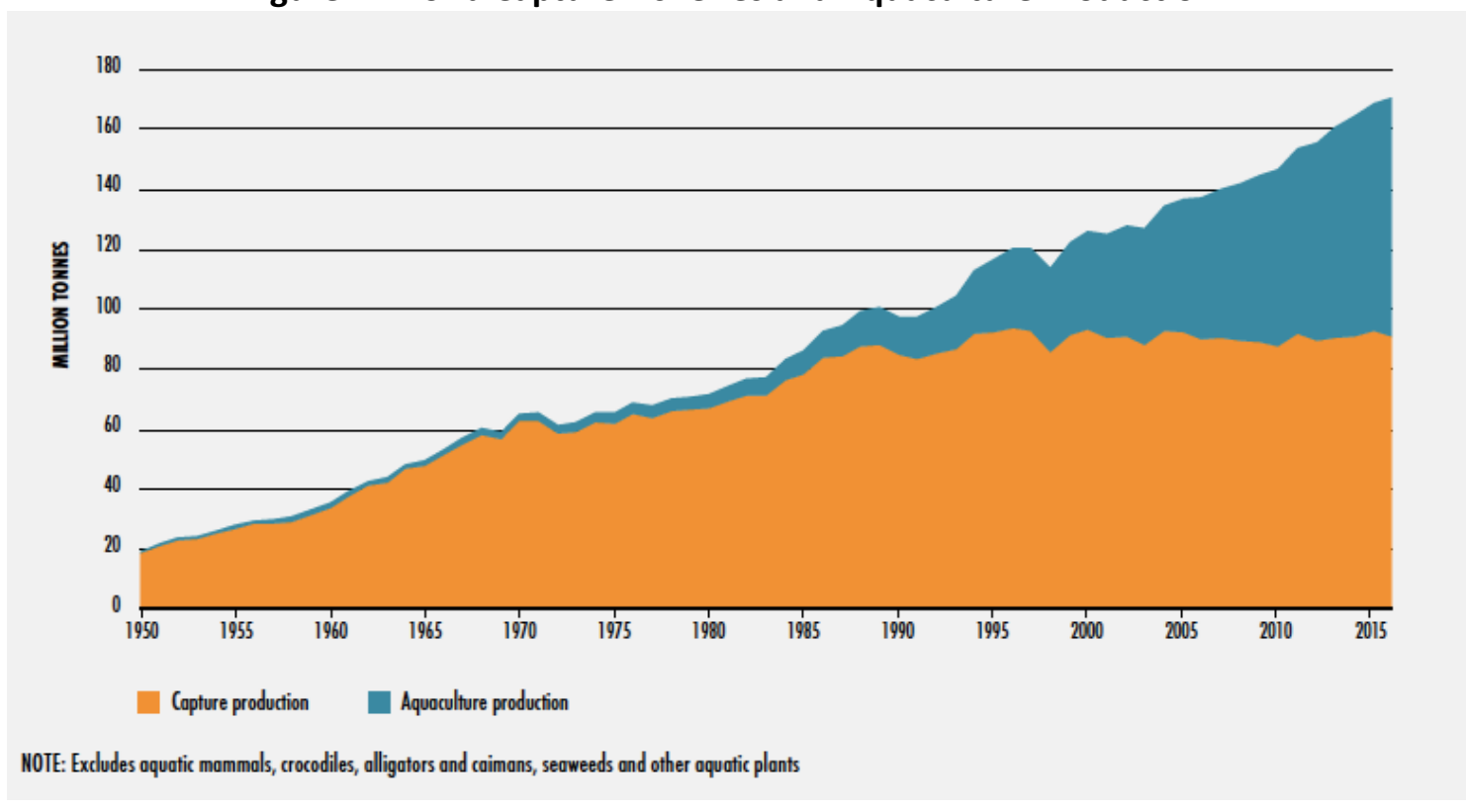

\footnotetext{
${ }^{1}$ Note: Seafood refers to fish, mollusks and crustaceans from capture fisheries and aquaculture, both from marine and freshwater environments

2 FAO. 2018. The State of World Fisheries and Aquaculture 2018 - Meeting the sustainable development goals. Rome. Licence: CC BY-NC-SA 3.0 IGO

${ }^{3}$ FAO. 2016b. The State of World Fisheries and Aquaculture 2016. Contributing to food security and nutrition for all. FAO, Rome. 200 pp.

${ }^{4}$ FAO. 2019 Food Outlook - Biannual Report on Global Food Markets - November 2019. Rome.

${ }^{5}$ FAO. 2018, p.4.

${ }^{6}$ FAO. 2019.

${ }^{7}$ Deutsch, L. et al. (2007) Feeding aquaculture growth through globalization: exploitation of marine ecosystems for fishmeal. Glob. Environ. Change 17, $238-249$.

${ }^{8} \mathrm{FAO} .2019$.

${ }^{9}$ FAO. 2018, p.3.
} 
Meanwhile, total aquaculture production in 2018 is estimated to be 83.2 million tons of food fish ${ }^{10}$, an increase from 2016 levels, which saw 80 million tons of food fish along with 30.1 million tons of aquatic plants and 37,900 tons of non-food products. While the average annual growth rate of the aquaculture sector has declined to 5.8 percent since its peak in the 1980s and 1990s, aquaculture remains one of the fastest growing major food production sectors (See Figure 1). ${ }^{11}$ Indeed, the total global production of farmed seafood continues to increase and is projected to match wild capture fisheries production in $2020 .{ }^{12}$ Researchers predict that while the global seafood trade will continue to increase, growth rates will slow and the growth in aquaculture will come at the expense of capture fisheries production. ${ }^{13}$

In 2018, the global seafood industry was valued at a record USD 163 billion, an almost USD 10 billion increase from 2017, driven by this strong global demand. ${ }^{14}$ However, experts note that the global seafood trade is currently characterized by value growth more than an increase in production volume. ${ }^{15}$ Despite the increasing value and demand for seafood, experts at the UN FAO express caution about the precarious state of seafood production pointing to geopolitical uncertainty, trade tariffs, and higher water temperatures resulting from climate change as influencing both aquaculture and wild capture fisheries. ${ }^{16}$

Table 1. 2019 UN FAO World Fish Market Statistics ${ }^{17}$

\section{WORLD FISH MARKET AT A GLANCE}

\begin{tabular}{|c|c|c|c|c|c|}
\hline & \multirow[t]{2}{*}{2017} & \multirow[t]{2}{*}{$\begin{array}{l}2018 \\
\text { estim. }\end{array}$} & \multicolumn{2}{|c|}{$\begin{array}{l}2019 \\
f^{\prime} \text { cast }\end{array}$} & \multirow{2}{*}{$\begin{array}{c}\text { Change: } \\
2019 \\
\text { over } \\
2018\end{array}$} \\
\hline & & & May & Nov & \\
\hline & \multicolumn{4}{|c|}{ million tonnes (live weight) } & $\%$ \\
\hline \multicolumn{6}{|l|}{ WORLD BALANCE } \\
\hline Production & 172.6 & 177.7 & 177.8 & 177.8 & 0.0 \\
\hline $\begin{array}{l}\text { Capture } \\
\text { fisheries }\end{array}$ & 92.5 & 94.5 & 91.3 & 91.3 & -3.4 \\
\hline Aquaculture & 80.1 & 83.2 & 86.5 & 86.5 & 3.9 \\
\hline $\begin{array}{l}\text { Trade value } \\
\text { (exports USD billion) }\end{array}$ & 156.5 & 162.9 & 164.5 & 160.5 & -1.4 \\
\hline $\begin{array}{l}\text { Trade volume } \\
\text { (live weight) }\end{array}$ & 64.9 & 65.1 & 64.5 & 64.3 & -1.2 \\
\hline Total utilization & 172.6 & 177.7 & 177.8 & 177.8 & 0.0 \\
\hline Food & 153.4 & 155.7 & 158.2 & 158.2 & 1.6 \\
\hline Feed & 14.6 & 17.5 & 15.0 & 15.0 & -14.2 \\
\hline Other uses & 4.7 & 4.6 & 4.6 & 4.6 & 0.0 \\
\hline \multicolumn{6}{|l|}{$\begin{array}{l}\text { SUPPLY AND DEMAND } \\
\text { INDICATORS }\end{array}$} \\
\hline \multicolumn{6}{|l|}{$\begin{array}{l}\text { Per caput } \\
\text { food consumption: }\end{array}$} \\
\hline Food fish (kg/yr) & 20.3 & 20.4 & 20.5 & 20.5 & 0.6 \\
\hline $\begin{array}{l}\text { From capture } \\
\text { fisheries (kg/year) }\end{array}$ & 9.7 & 9.5 & 9.3 & 9.3 & -2.0 \\
\hline $\begin{array}{l}\text { From aquaculture } \\
\text { (kg/year) }\end{array}$ & 10.6 & 10.9 & 11.2 & 11.2 & 2.8 \\
\hline \multirow[t]{2}{*}{$\begin{array}{l}\text { FAO FISH PRICE INDEX } \\
(2002-2004=100)\end{array}$} & 2017 & 2018 & & $\begin{array}{c}2019 \\
\text { ten-Sept }\end{array}$ & $\begin{array}{c}\text { \%Change } \\
\text { Jan/Sept } \\
2019 \text { over } \\
\text { Jan/Sept } \\
2018\end{array}$ \\
\hline & 158 & 158 & & 156 & -2.1 \\
\hline
\end{tabular}

Source of the raw data for the FAO Fish Price Index: EUMOFA, INFOFISH, INFOPESCA, Statistics Norway. Refer to Appendix table 29 for further detalk.

${ }^{10}$ FAO. 2019.

${ }^{11}$ FAO. 2018, p.4.

12 RaboBank. (April 2019). World Seafood Map 2019: Value Growth in the Global Seafood Trade Continues.

https://research.rabobank.com/far/en/sectors/animal-protein/world-seafood-trade-map.html

13 ibid.

14 RaboBank, 2019

15 RaboBank, 2019

16 FAO. 2019

${ }^{17}$ FAO. 2019. 


\subsubsection{United States seafood supply and demand}

Meanwhile, in the United States, consumer demand for seafood has been steadily increasing over the past decade. In 2017, Americans consumed 16 pounds of seafood per capita, an increase of 1.1 pounds from the prior year. ${ }^{18}$ Despite this increase, the U.S. seafood palate remains relatively limited with little variation among consumers' top seafood preferences for well over a decade. That said, there is some indication that American tastes may be diversifying. In 2016, the top ten species represented 90 percent of all the seafood Americans consumed, however in 2017, the top ten species made up only 84 percent of the total seafood consumed (Table 2). ${ }^{19}$ Whether this is an indication of product availability or a shift in consumer preferences is unclear.

Table 2. 2017 U.S. Per-Capita Consumption by Species in Pounds ${ }^{20}$

\begin{tabular}{|l|l|l|}
\hline Rank & Species & Per Capita Consumption (lbs) \\
\hline 1 & Shrimp & 4.40 \\
\hline 2 & Salmon & 2.41 \\
\hline 3 & Canned Tuna & 2.10 \\
\hline 4 & Tilapia & 1.8 \\
\hline 5 & Alaska Pollock & 0.78 \\
\hline 6 & Pangasius & 0.71 \\
\hline 7 & Cod & 0.66 \\
\hline 8 & Crab & 0.52 \\
\hline 9 & Catfish & 0.53 \\
\hline 10 & Clams & 0.31 \\
\hline Total All Species & 16.00 \\
\hline
\end{tabular}

In 2017, U.S. commercial capture fishery production was valued at USD 5.4 billion for 9.9 billion pounds of landed catch. Of the total catch, approximately 83 percent is directed towards human consumption while 17 percent is used as animal feed. ${ }^{21}$ Aquaculture, on the other hand, plays a more minor role in overall domestic seafood production, producing 633.5 million pounds valued at USD 1.45 billion. ${ }^{22}{ }^{23}$ That said, domestic freshwater and marine aquaculture production is growing in both volume and value. Between 2009 and 2014, aquaculture production increased an average of 3.3 percent per year, ${ }^{24}$ however between 2015 and 2016 the volume of farmed seafood produced increased by only one percent while the value increased by over four percent. Despite this modest growth, the U.S. remains a minor player in global aquaculture, ranking $16^{\text {th }}$ in the world in terms of annual production. ${ }^{25}$

A net importer of seafood, the U.S.'s top importing countries include China, Thailand, Canada, Indonesia, Vietnam and Ecuador. NOAA Fisheries reports conflicting figures regarding the total amount of seafood imported into the U.S. Some sources assert that 80 percent ${ }^{26}$ of the seafood that the U.S. consumes is imported while others contend the figure to be 90 percent ${ }^{27}$ with approximately half of those imports from aquaculture. ${ }^{28}$ New research, however, disputes these figures arguing that imports are more likely between 62 and 65 percent since, among other things, a percentage of government-reported imports is seafood caught or produced in the

\footnotetext{
${ }^{18}$ National Fisheries Institute (2017). Top 10 list for seafood consumption. https://www.aboutseafood.com/about/top-ten-list-for-seafood-consumption/

19 ibid.

20 ibid.

${ }^{21}$ National Marine Fisheries Service. (2018). Fisheries of the United States, 2017. U.S. Department of Commerce, NOAA Current Fishery Statistics No. 2017. https://www.fisheries.noaa.gov/resource/document/fisheries-united-states-2017-report

22 ibid.

${ }^{23}$ Note: 2017 data for U.S. aquaculture production is not yet available as aquaculture lags commercial fisheries data by one year.

${ }^{24}$ National Marine Fisheries Service (2018)

${ }^{25}$ National Marine Fisheries Service (2018)

${ }_{26}^{6}$ NOAA FishWatch (https://www.fishwatch.gov/sustainable-seafood/the-global-picture), visited January $19,2020$.

${ }_{27}$ NOAA Fisheries (https://www.fisheries.noaa.gov/national/aquaculture/us-aquaculture), visited January 19, 2020

28 ibid.
} 
U.S., exported to other countries for processing, and then imported back into the U.S. for distribution and sale. ${ }^{29}$ Likewise, researchers estimate that 35 to 38 percent of seafood consumed in the U.S. is of domestic origin. ${ }^{30}$

This distinction is important as the government has been relying on potential overestimates of seafood imports and the apparent seafood trade deficit to justify expansion of U.S. wild capture fisheries and expedite domestic aquaculture development. However, because domestic wild capture fisheries often command a higher price than imports, it is unlikely that expanding domestic fisheries will reduce our reliance on or replace less expensive imports. What's more, increasing catch volumes and/or extending fishing activity into ecologically important habitat areas pose significant threats to the long-term sustainability of marine species as well as unique and vulnerable marine ecosystems. Even so, as the volume and value of seafood imports to the U.S. continues to grow - the value of seafood imports increased from just over USD 10 billion in 2002 to approximately USD 23 million in 2017 - there are justifiable concerns about the impact this disparity will have on domestic fisheries and aquaculture. ${ }^{31}$

\subsection{Environmental costs and benefits of fisheries and aquaculture}

Relative to plant- and cell-based seafood alternatives, the environmental impacts of wild capture fisheries and aquaculture are well-documented. Even so, given the global diversity of fisheries and aquaculture operations, it is difficult to generalize across these sectors, as the specific impacts can be highly variable depending on the region, the fishery, and/or the mode of aquaculture production. Likewise, there are few product-specific full lifecycle assessments (LCAs) for seafood to provide us with a holistic view of the environmental footprint of different seafood products relative to each other and their emerging plant-and cell-based analogs. In the absence of more comprehensive comparative data on conventional seafood products, we examine the broader environmental costs and benefits of the sector and the general categories of impact associated with both wildcapture fisheries and aquaculture to provide a baseline for comparison with plant- and cell-based seafood.

\subsubsection{Wild capture fisheries}

Most of global food production is now domesticated and/or cultivated, but wild- capture fisheries represent one of the last vestiges of humans' hunting and gathering past. Still, the metrics for evaluating the environmental footprint of fisheries are not unlike those used to assess the impact of other food production sectors. Overfishing, habitat destruction, bycatch and discards associated with different fisheries and gear types can reduce biodiversity and alter ecosystem dynamics. Meanwhile fuel consumption, as well as onboard freezing and processing operations, can consume energy and contribute to greenhouse gas emissions. Water and chemical use is less an issue than it is for aquaculture and terrestrial agriculture, but like other modes of food production, waste is a persistent issue that occurs at every node in the seafood supply chain.

\section{o $\quad \underline{\text { Stock status }}$}

A 2018 UN FAO report estimates that 33 percent of global fish stocks are overexploited or "overfished," meaning their population size is too low and jeopardizes the stock's ability to produce the maximum sustainable yield. ${ }^{32}{ }^{33}$ Meanwhile, 60 percent of world fisheries are fully exploited, which mean these fisheries are operating

\footnotetext{
${ }^{29}$ Gephart, J.A., Froehlich, H.A., and Branch, T.A. (2019). Opinion: To create sustainable seafood industries, the United States needs a better accounting of imports and exports. Proceedings of the National Academy of Sciences May 2019, 116 (19) 9142-9146; DOI:10.1073/pnas.1905650116

30 ibid.

${ }^{31}$ RaboBank, 2019.

32 FAO. 2018, p.5.

${ }^{33}$ Note: The maximum sustainable yield (MSY) for a given fish stock is the highest possible annual catch that can be sustained over time, by keeping the stock at the level producing maximum growth. The MSY refers to a hypothetical equilibrium state between the exploited population and the fishing activity.
} 
at or close to optimal yield, ${ }^{34}$ with no expected room for further expansion. ${ }^{35}$ Some experts argue that a "fully exploited" fishery is sustainable since it has not crossed the threshold to being overfished, but increasingly marine ecologists point to the fact that whether a species is overfished is not the determining factor in a fishery's sustainability. Indeed, the single species management approach employed by many fishery managers often does not incorporate critical ecosystem considerations including "species interactions, bycatch, changes in ecosystem structure and gear impacts on habitat." ${ }^{36}$ What's more, many fishery stock assessments are based on incomplete and under-reported catch and landings data so information regarding of stock sizes and associated sustainable fishing levels, may be overestimated. Excess removal of species can disrupt trophic interactions and ecosystem structure and undermine the goal of promoting sustainable fisheries and a healthy, productive and resilient ecosystem.

As of 2018 , only 244 of the 479 United States federally managed fish stocks or stock complexes have been assessed to determine their overfished status. Of those 244,43 (18 percent) are designated as overfished. ${ }^{37}$ Meanwhile, of the 321 stocks and stock complexes with known overfishing status, 28 stocks are currently subject to overfishing according to NOAA's 2018 Report to Congress on the Status of U.S. Fisheries. ${ }^{38}$ Compounding the low biomass and unsustainable rates of fishing associated with many commercially targeted fish stocks are the impacts of climate change, ocean acidification, coastal development and pollution, habitat destruction, and an increasingly industrialized ocean space.

\section{o $\quad$ Habitat impacts}

Whether it's a kelp forest, coral reef, seagrass bed, estuary, or the deep sea, coastal and marine habitats help shelter and sustain a wide variety of life. Damage to and/or the loss of habitat can make species more vulnerable to predation, eliminate critical food sources, and disrupt spawning and other natural behaviors. This can have devastating effects on individual species and compromise the productivity and resiliency of the broader ecosystem. While there are a range of anthropogenic stressors contributing to habitat loss and alteration (coastal development, pollution, etc.), fishing can impact coastal and marine habitats in variety of ways.

Impacts may be physical, such as the installation of artificial reefs, fishery aggregating devices (FADs), or casitas, ${ }^{39}$ all of which serve to create new habitat to attract marine life for commercial fisheries. Scientists debate whether these structures produce more fish or whether they simply act as attractants drawing marine life from other parts of the sea and concentrating them around a structure. FADs are particularly controversial as they tend to attract a diverse array of marine life including protected species and juveniles, such that fisheries that set on FADs (e.g., tuna purse seine fisheries) often capture non-target and protected species (e.g., sea turtles) alongside their target catch.

Fishing impacts on habitat can also be mechanical through the plowing effect of dredges, bottom trawls and other bottom tending mobile gear, which scour the seafloor disturbing or destroying everything in their path including vegetation, coral, rock structures, invertebrates, etc. Similarly, trap and pot fisheries can cause damage to habitat by snagging and entangling fragile structures including corals and sponges. The type and severity of

\footnotetext{
${ }^{34}$ Note: Optimum yield (OY) is the amount of fish harvested that: (a) will provide the greatest overall benefit to the national economy, particularly with respect to food production and recreational opportunities, and taking into account the protection of marine ecosystems; or (b) is prescribed as such on the basis of the maximum sustainable yield from the fishery, as qualified by any relevant economic, social, or ecological factors; and (c) in the case of an over fished fishery, provides for rebuilding to a level that produces the maximum sustainable yield in the fishery.

${ }^{35}$ FAO. 2018, p.5.

${ }^{36}$ Trochta J.T., Pons M., Rudd M.B., Krigbaum M., Tanz, A., and Hilborn, R. (2018). Ecosystem-based fisheries management: Perception on definitions, implementations, and aspirations. PLoS ONE 13 (1): e0190467. https://doi.org/10.1371/journal. pone.0190467

${ }^{37}$ NOAA Fisheries. (July 2019). 2018 Status of Stocks Report to Congress. https://www.fisheries.noaa.gov/national/2018-report-congress-status-usfisheries

${ }^{38}$ ibid.

${ }^{39}$ Note: "Casitas" (or "little houses") are found in lobster fisheries throughout Latin America and parts of Australia. Spiny lobsters seek out shelter in the covered structures which work as well as baited traps according to some.
} 
fishing impacts on marine habitats are highly variable and depend largely on the location, habitat type, and method of fishing.

\section{$0 \quad$ Waste}

While not unique to fisheries, waste is a persistent problem that occurs at every node in the seafood supply chain from "bait to plate." From bycatch and discards to downstream spoilage, the amount of waste in wildcaught fisheries and aquaculture has significant implications for environmental sustainability, as well as food security. According to a study from John Hopkins Center for a Livable Future that looked at waste in the seafood supply chain between 2009 and 2013, 40 to 47 percent of 4.7 billion pounds of seafood destined for U.S. markets every year (from both domestic and imported sources), ended up as waste (about 2.3 billion pounds). ${ }^{40}$ Looking at loss attributed to bycatch and discards, distribution and retail operations, and consumption, researchers concluded that the greatest losses occurred at the consumer level (51-63 percent) followed by bycatch and discards (16-32 percent), and distribution and retail (13-16 percent). ${ }^{41}$ All things considered, they concluded that the amount of seafood wasted is enough to meet the protein needs of 10 to 12 million people for a full year.

Poor handling and high levels of spoilage of seafood contribute to post-capture waste. Meanwhile, economic and regulatory pressures influence the rates of bycatch and discards. ${ }^{42}$ Approximately 10 percent of the world's annual catch is tossed back into the ocean as discards. ${ }^{43}$ In the U.S., research estimates that as much as 2 billion pounds (roughly 20 percent of the total catch) of fish are discarded by U.S. fisheries each year. ${ }^{44}$ In addition to the ecological consequences, this volume of needlessly wasted catch amounts to an annual loss to the U.S. economy of at least USD 1 billion. ${ }^{45}$

A separate source of non-biological waste that contributes to the environmental footprint of fisheries and should be accounted for in life-cycle assessments stems from the plastics and other packaging used and discarded in the distribution of seafood from the point of capture to the consumer.

\section{o Illegal, unreported and unregulated (IUU) fishing}

IUU fishing includes fishing activities that break the law (illegal) or occur beyond the jurisdiction of fisheries management (unregulated). Illegal fishing, which has garnered significant concern in recent years, refers to fishing without a license or authorization, fishing in a closed area and/or during a prohibited period, fishing with prohibited gear, exceeding established quotas, and/or fishing prohibited species. By avoiding the costs associated with licensing and regulatory compliance (e.g., catch limits, gear requirements, time/area restrictions), illegal fishing creates unfair competition, disadvantaging legitimate commercial fishers and the marine ecosystem. Since the catch associated with illegal fishing goes unreported, it contributes to uncertainty around the total catch estimates and population assessments needed to sustainably manage fishery resources. Likewise, where fishers are not constrained by management requirements, the risk of unsustainable fishing

\footnotetext{
${ }^{40}$ Love, DC, Fry, JP, Milli, MC, Neff, RN. (2015). Wasted seafood in the United States: Quantifying loss from production to consumption and moving toward solutions. Global Environmental Change, Vol. 35. https://doi.org/10.1016/j.gloenvcha.2015.08.013

41 ibid.

${ }^{42}$ Note: Discards may be due to regulatory requirements ("regulatory discards") such as a species is too small, out of season, or is otherwise prohibited. It may also be due to economic pressures ("economic discards") including fish that are damaged or malformed making them unmarketable, non-target species with less market value, or fish that are partially discarded because fishers are only targeting part of the fish (e.g., Alaska pollock roe). In some cases, fishers will continue to fish after they have reached their limit with the goal of catching larger, higher value fish ("high-grading"). In the meantime, smaller, lower valued fish and non-target species are discarded dead or dying.

${ }^{43}$ Zeller, D., Cashion, T., Palomares, M., Pauly, D. (2018) Global marine fisheries discards: A synthesis of reconstructed data. Fish

Fisheries.19: 30- 39. https://doi.org/10.1111/faf.12233

${ }^{44}$ Keledijian, A., Young, S., Grubb, C., and Cono-Stocco, D. (2014). Wasted Cash: The Price of Waste in the U.S. Fishing Industry. Oceana.

https://oceana.org/sites/default/files/reports/wasted_cash_report_final.pdf

45 ibid.
} 
practices, destructive and indiscriminate gear and/or catches that include vulnerable and/or protected species is that much greater.

\section{o Greenhouse Gas Emissions}

Research indicates that current food consumption patterns in developed countries exceed what is considered "sustainable" by at least a factor of four. ${ }^{46}$ Already, the production, distribution and consumption of food accounts for a quarter of global anthropogenic greenhouse gas emissions (GHG), ${ }^{47}$ but as incomes and affluence in developing countries increase so do diets rich in animal protein. According to the United Nations' Food and Agriculture Organization, animal agriculture accounts for approximately 18 percent of total annual global anthropogenic greenhouse gas emissions. Included in these calculations are the production of feed crops, enteric fermentation, the manufacturing of fertilizer, and shipment of meat, eggs, and dairy. ${ }^{48}$ If this trend continues, scientists predict that the GHG emissions associated with food production are likely to grow by over 30 percent by $2050 .^{49}$

The capture fisheries sector is an important part of the global food industry, however it is underrepresented in measurements of GHG emissions from food production. ${ }^{50}$ Since fishing is a fuel-intensive industry, most of the GHG emissions come from the burning of fossil fuels. But within the fisheries sector, emissions are not uniform and there is a high degree of variability between target species, gear types and the environments in which a fishery operates. Indeed, crustacean-targeting fisheries tend to be more carbon intensive whereas fisheries for small pelagic species are less carbon intensive. ${ }^{51}$ What's more, as more fisheries become depleted, fishers are having to travel further to locate their catch, using more fuel, and generating more emissions.

A 2018 study observed that overall emissions from ocean fisheries are increasing while landings have remained relatively constant. ${ }^{52}$ They further estimated that emissions from the global fishing industry grew by two percent between 1990 and 2011, and in 2011, the world's fishing fleets burned "40 billion litres of fuel and emitted 179 million tonnes of $\mathrm{CO} 2$ equivalent (CO2-eq) GHGs to the atmosphere, or $2.2 \mathrm{~kg}$ CO2-eq per kilogram of landed fish and invertebrates." 53

While fishery specific data regarding GHG emissions are limited, efforts are underway to incorporate carbon footprint data into metrics around seafood sustainability relative to particular species and production methods. In 2010, the Monterey Bay Aquarium's Seafood Watch program and Dalhousie University joined forces to create an online Seafood Carbon Emissions Tool. (http://seafoodco2.dal.ca) The Tool combines information from life cycle assessments, fuel use datasets, and industry and government reports to estimate the carbon footprint (on a per kg of weight and per kg of protein basis) for over 150 seafood products from wild fisheries and aquaculture. Given the complex and highly variable nature of the seafood supply chain, the Tool's calculations of GHG emissions does not extend beyond the dock or farm gate and so does not include the emissions associated with processing, storage and transport. As such, it's utility in providing a baseline for comparing the carbon footprints associated with different seafood products to plant- and cell-based seafood is limited to the primary production stage.

\footnotetext{
${ }^{46}$ Carlsson-Kanyama, A. (1998). Climate change and dietary choices - how can emissions of greenhouse gases from food consumption be reduced? Food Policy 23, 277-293.

${ }^{47}$ Parker, R.W.R., Blanchard, J.L., Gardner, C. et al. Fuel use and greenhouse gas emissions of world fisheries. Nature Clim Change 8, 333-337 (2018) doi:10.1038/s41558-018-0117-x

${ }^{48}$ Steinfeld, H., Gerber, P., Wassenaar, T., Castel, V, Rosales ,M, and de Haan, C. (2006). Livestock's long shadow: environmental issues and options (Rome: Food and Agriculture Organization of the United Nations, pp. xxi, 86, 88, 99-101).

49 Tilman, D. \& Clark, M. (2014). Global diets link environmental sustainability and human health. Nature 515, 518-522.

${ }^{50}$ Parker, Blanchard, Gardner et al., 333-337.

51 ibid.

52 ibid.

53 ibid.
} 


\subsubsection{Aquaculture}

The growing demand for seafood is increasingly being met by aquaculture. Aquaculture is not unlike agriculture when it comes to environmental impacts, however the relative newness and rapid expansion and diversification in aquaculture globally has, in many regions, outpaced the capacity of governments to develop strong management frameworks to ensure that environmental impacts are sufficiently mitigated. Where governance is lacking, market-based incentives, including certification and ranking programs, are playing an increasingly important role by creating standards and providing guidance to support more sustainable aquaculture and inform good governance.

Fish farming offers opportunities to diversify production through polyculture or through integration with other production activities (e.g., multi-trophic level aquaculture of seaweed, mussels and oysters), however it is also becoming increasingly intensified and its negative impacts pose a threat to human communities and ecosystems worldwide. ${ }^{54}$ That said, the environmental impacts of aquaculture are not uniform across all geographies, species and modes of production. Indeed, some species such as oysters, clams and mussels, which require no feed and filter the surrounding water, are generally regarded as having a net positive impact on the environment. Likewise, closed containment recirculating aquaculture systems are promoted as the more sustainable alternative to open systems (although energy use and feed remain a challenge). Still, as aquaculture operations struggle to maximize growth efficiency and minimize costs, they are confronted with a variety of sustainability challenges. Poorly managed, aquaculture can have global impacts with its demand for fish feed and can also have local impacts by damaging coastal wetlands and nearshore habitats and stressing ecosystem functions through the addition of feed residues, waste, antibiotics, hormones, diseases, and alien species to the local environment.

\section{o $\quad$ Feed}

One of the criticisms of aquaculture, particularly in the case of carnivorous species, is that the fish feed that is often required to produce farmed seafood, is exacerbating rather than relieving pressure on wild fish populations. Indeed, 20-35 percent of wild-capture fishery landings is directed towards the production of fishmeal and fish oil for feed in terrestrial animal- and fish-farming operations. What's more, two-thirds of current aquaculture production relies on fishmeal additives, an increase of 10 percent since $1980 .{ }^{55}$ While innovations in feed are helping to lower the forage fish dependency ratio (FFDR), 56 "farming of fed aquatic animal species has grown faster than that of unfed species." ${ }^{57}$ While unfed species, including filter-feeding finfish, bivalve mollusks and seaweeds, represent a smaller percentage of overall aquaculture production, their total volume is increasing globally.

Aquaculture feed derived from land-based agriculture is also problematic as it is putting added pressure on land and water resources around the world. Arable land that might otherwise be used to grow food for human consumption is being cultivated for aquaculture feed. Emerging innovations in aquaculture feed including the use of algae, insects and bacteria may help to reduce some of the pressure on wild fisheries and terrestrial ecosystems.

\section{o Eutrophication}

Pollution and increased nutrient loading resulting from discharge and effluent from fish-farming operations can contribute to eutrophication in local environments. The deposition of fish waste, unconsumed feed, and

\footnotetext{
${ }^{54}$ FAO. 2019. The State of the World's Biodiversity for Food and Agriculture, J. Bélanger \& D. Pilling (eds.). FAO Commission on Genetic Resources for Food and Agriculture Assessments. Rome. 572 pp. (http://www.fao.org/3/CA3129EN/CA3129EN.pdf)

${ }^{55}$ FAO. 2014. The state of fisheries and aquaculture ed. Food and Agriculture Organisation United Nations.

${ }^{56}$ Note: Forage Fish Dependency Ratio (FFDR): the quantity of wild fish used in feeds in relation to the quantity of farmed fish produced, in fed aquaculture systems. (IFFO 2017, https://www.iffo.net/position-paper/forage-fish-dependency-ratio-ffdr)

${ }^{57}$ FAO. 2018. The State of World Fisheries and Aquaculture 2018 - Meeting the sustainable development goals. Rome. Licence: CC BY-NC-SA 3.0 IGO, p.5.
} 
decomposing fish carcasses can create hypoxic conditions in nearby waters threatening the health and survival of marine and aquatic life. What's more, pesticides and antibiotics used to prevent and control disease can make their way into the surrounding environment adversely impacting local species.

\section{$0 \quad$ Land use and habitat impacts}

The conversion of land and the water column for aquaculture can have deleterious effects on the local ecosystem. For example, the removal of ecologically important mangrove forests to make room for shrimp ponds has led to massive coastal erosion, loss of biodiversity, and poor water quality in many parts of the world. ${ }^{58}$ Mangroves and other coastal ecosystems offer critical ecosystem services by serving as a barrier to storm surges, providing nursery habitats for juvenile fish, filtering water and absorbing and storing carbon from the atmosphere. ${ }^{59}$

\section{O Water use}

Producing feed for livestock and aquaculture production is resource intensive and increasing pressure is being put on global water resources due to the freshwater demands of aquaculture feed production. Feed production consumes eight percent of global human water use, mainly for the irrigation of feed crops and nearly 33 percent of total arable land is dedicated to feed-crop production for aquaculture and animal agriculture. ${ }^{60}$ Indeed, aquaculture feed production is the biggest contributor to aquaculture's impact on freshwater resources. As producers look to replace fish meal and fish oil with plant-based ingredients for feed, the water footprint of aquaculture production, which combines the consumption of freshwater with the amount of water pollution from crop production, is likely to grow. Researchers estimate that the total global water footprint of commercial aquaculture feed was $31-35 \mathrm{~km}^{3}$ in 2008 with the top five contributors to the total water footprint of commercial feed being Nile tilapia, Grass carp, Whiteleg shrimp, Common carp and Atlantic salmon, which collectively have a water footprint of $18.2 \mathrm{~km}^{3}{ }^{61}$

The freshwater footprint of aquaculture varies between different species, production modes and location, and should be assessed in the context of scarcity. Indeed, some parts of the world have abundant water resources where the demands of aquaculture for freshwater may have minimal impact. Meanwhile, freshwater can be scarce in other regions such that the demands for freshwater in aquaculture can lead to severe water stress and shortages. When water use is weighted by local water scarcity, you can get a more accurate picture of the impact that aquaculture has. Figure 2 synthesizes macro-level data to illustrate the scarcity-weighted water footprint of farmed fish and prawns relative to the most common agricultural crops used in plant-based seafood products. $^{62}$

\footnotetext{
${ }^{58}$ B.K. van Wesenbeeck, T. Balke, P. van Eijk, F. Tonneijck, H.Y. Siry, M.E. Rudianto, J.C. Winterwerp. (2015). Aquaculture induced erosion of tropical coastlines throws coastal communities back into poverty. Ocean \& Coastal Management, Volume 116, 466-469.

https://doi.org/10.1016/j.ocecoaman.2015.09.004. (http://www.sciencedirect.com/science/article/pii/S0964569115300223)

${ }^{59}$ ibid.

${ }^{60}$ FAO. 2017. Global database of GHG emissions related to feed crops: Methodology. Version 1. Livestock Environmental Assessment and Performance Partnership. FAO, Rome, Italy.

${ }^{61}$ Pahlow, Markus \& van Oel, Pieter \& Mekonnen, Mesfin \& Hoekstra, Arjen. (2015). Increasing pressure on freshwater resources due to terrestrial feed ingredients for aquaculture production. Science of The Total Environment. 536. 847-857. 10.1016/j.scitotenv.2015.07.124.

62 Poore, J., \& Nemecek, T. (2018). Reducing food's environmental impacts through producers and consumers. Science, 360(6392), 987-992
} 
Figure 2. Scarcity-weighted water use per kilogram of food product ${ }^{63}$

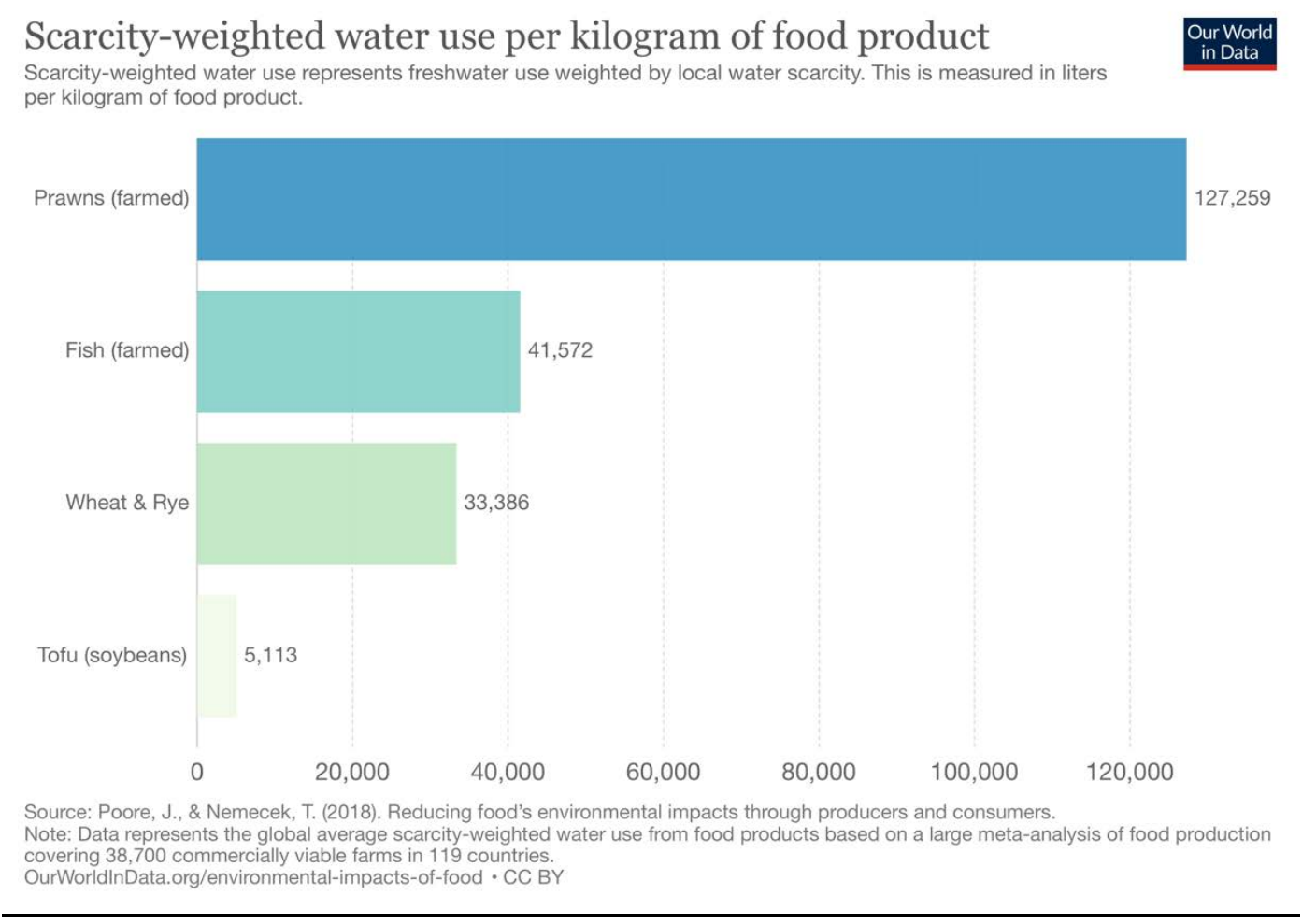

\section{O Escapes and disease}

One of the impacts that has generated the greatest controversy, particularly with regards to salmon farming, is that of escapement. When farming operations (net pens or ponds) are connected to natural waterbodies, fish can escape and mix with wild populations, effectively becoming invasive species. Escapes of farmed fish can spread diseases such as sea lice to wild populations and interfere with their natural behavior and survival by increasing competition for food, habitat and spawning partners. Spawning and reproduction between farmed and wild populations can also influence the genetic integrity of wild populations and decrease their fitness and ability to survive.

\subsection{Socio-Economic Costs and Benefits Fisheries and Aquaculture}

\subsubsection{Economic and Food Security}

If current human population trends continue unabated, the world will need to double its global food production by 2050. Increasingly, industry and world leaders are turning towards seafood to ensure food security and provide a critical source of protein for a growing global population. Already, an estimated 4.3 billion people (more than half of the current global human population of 7.8 billion) rely on seafood for 15 percent of their animal protein intake and another 59.6 million (85 percent of which are in Asia) depend on aquaculture and wild capture fisheries for their livelihoods. ${ }^{64}$ While the proportion of those engaged in wild capture fisheries has declined by 15 percent since 1990, there has been a corresponding increase in the proportion of those engaged in farmed seafood production. ${ }^{65}$

\footnotetext{
63 ibid.

${ }^{64}$ FAO. 2018. The State of World Fisheries and Aquaculture 2018 - Meeting the sustainable development goals. Rome. Licence: CC BY-NC-SA 3.0 IGO, p.5.

65 ibid.
} 
In the U.S., the seafood industry plays an important economic role supporting 1.7 million jobs and generating USD 212 billion in revenue from "on-the-water" jobs and sales as well as seafood processing, packaging, wholesale and retail jobs and sales. ${ }^{66}$ Likewise, the industries that provide critical supply and infrastructure support to commercial fisheries including marinas, navigational services, port and harbor operations, ship-and boat-building operations are also included in government estimates of the socio-economic contributions of the seafood industry. Notably, while the U.S. plays a relatively small role in terms of global aquaculture production, it is a major player in aquaculture, providing "advanced technologies, feed, equipment and investment capital to other producers around the world." ${ }^{\prime 6}$

Despite the importance of seafood for economic and food security, some researchers are skeptical that increasing overall seafood production is the solution to feeding a growing global population. Indeed, wild capture fisheries have both biological and ecological limits and aquaculture is a diverse and evolving industry that, in many regions of the world, operates without strong governance and sustainability limits. A 2017 report by the World Bank estimated that poor management and overexploitation of fishery resources costs the global economy USD 83 billion every year. ${ }^{68}$ Moreover, with one-third of global fisheries production going towards animal feed (including aquaculture) rather than direct human consumption, ensuring food security may be less about producing more seafood and more about strengthening management, decreasing waste (throughout the supply chain), increasing the proportion of seafood produced for direct human consumption, and accelerating the development of innovative non-fish feed ingredients for aquaculture. ${ }^{69}$

What's more, government subsidies of fisheries, in many instances, are providing perverse incentives that undermine long-term economic and food security in many parts of the world. For example, new research describes high seas fisheries as playing an insignificant role in ensuring food security. ${ }^{70}$ High seas fishing for deep water and pelagic species is conducted primarily by larger industrial fleets that cater mainly to upscale markets due to the high costs of production (e.g., labor and fuel costs). But without government subsidies, researchers estimate that as much as 54 percent of high seas fishing would not be profitable. ${ }^{71}$

But government subsidies are not limited to high seas fisheries and an estimated USD 22 billion is spent every year by governments around the globe to offset the cost of fishery-related expenses such as fuel, fishing gear, expanding vessel capacity, and constructing new vessels. ${ }^{72}$ While not all subsidies are harmful, capacity enhancing subsidies for large-scale/industrial fisheries can disproportionately impact coastal communities whose lives and livelihoods are tied to the sea. Increasing fishing capacity (e.g., the number of vessels, engine power, and technological capacity) leads to more fishing effort and often, less catch. This decrease in catch per unit effort (CPUE) is frequently an indicator of declining fish stocks, which can be reflected in smaller catches and a shift in the age and size distribution of fish populations. Small-scale fishers and coastal communities are likely to feel the impact of these changes more acutely with smaller catches, smaller fish sizes, and less commercially valuable species. ${ }^{73}$ Likewise, subsidies create a competitive disadvantage for local fishers who are often competing for dwindling catch against well-subsidized industrial-scale fishers who can access more productive fishing grounds and more lucrative foreign markets. ${ }^{74}$

\footnotetext{
${ }^{66}$ National Marine Fisheries Service. (2018). Fisheries Economics of the United States, 2016. U.S. Dept. of Commerce, NOAA Tech. Memo. NMFS-F/SPO187a, $243 \mathrm{p}$.

67 ibid.

${ }^{68}$ World Bank (2017). The Sunken Billions Revisited: Progress and Challenges in Global Marine Fisheries, World Bank Publications, The World Bank, number 24056.

${ }^{69}$ Watson, R., Nowara, G., Hartmann, K. et al. Marine foods sourced from farther as their use of global ocean primary production increases. Nat Commun 6, 7365 (2015) doi:10.1038/ncomms8365

${ }^{70}$ Sala, E., Mayorga, J., Costello, C., Kroodsma, D., Palomares, M.L.D., Pauly, D., Sumaila, U.R., Zeller, D. (2018). The economics of fishing the high seas. Sci. Adv. 4, eaat2504.

${ }^{71}$ ibid.

${ }^{72}$ Sumaila, U.R., Ebrahim, N., Schuhbauer, A., Skerritt, D., Li, Y., Kim, H., Mallory, T., Lam, V. and Pauly, D. (2019). Updated estimates and analysis of global fisheries subsidies. Marine Policy. 109. 10.1016/j.marpol.2019.103695.

${ }^{73}$ Crispino, M. (21 November 2019). Five Ways Harmful Fisheries Subsides Impact Coastal Communities. World Wildlife Fund.

https://www.worldwildlife.org/stories/5-ways-harmful-fisheries-subsidies-impact-coastal-communities

${ }^{74}$ ibid.
} 


\subsubsection{Unfair and exploitative labor practices}

In addition to subsidies, some fisheries and aquaculture operations also rely on unfair and exploitative labor practices to lower costs and increase profits. While there is broad recognition that human trafficking and forced labor are issues of concern in the global seafood industry, ${ }^{75}$ reliable estimates are limited given the invisible nature of most at-sea fisheries operations. In recent years, however, there has been heightened scrutiny around the issues of labor rights and worker abuse in the seafood industry. Recognizing the reputational and financial risks associated with labor abuse in the seafood supply chain, major seafood buying companies are increasingly partnering with government agencies as well as environmental, human rights, and labor NGOs to develop tools and strategies to better detect and deter human rights abuses in the seafood industry. Likewise, a collaboration of seafood certification and rating groups including Monterey Bay Aquarium's Seafood Watch program, Fair Trade USA, the Aquaculture Stewardship Council, and the Marine Stewardship Council among others developed a "Framework for Social Responsibility in the Seafood Sector" to help seafood businesses assess and improve their performance on human rights and social issues. ${ }^{76}$ Human rights and labor abuses, while often driven by greed, corruption, socio-economic and cultural inequities and economic conditions, are closely linked to environmental degradation. Economic pressures are aggravated by decreasing catch from overfishing and can lead operators to cut corners with crew health, safety, and compensation. ${ }^{77}$

\subsubsection{Illegal, unreported and unregulated fishing}

Illegal, unregulated and unreported (IUU) fishing not only compromises the health of our oceans, but costs the global economy an estimated USD 10 to 35 billion per year. ${ }^{78}$ The U.S. fishery alone could be losing close to USD 1 billion per year due to price suppression associated with the import illegal seafood into the U.S. ${ }^{79}$ What's more, illegal fishing is frequently associated with other maritime and transnational crimes including human, wildlife, and drug trafficking, piracy, slavery-at-sea, and terrorism. While the U.S. has measures in place to restrict port entry and access to port services to vessels identified as engaging in IUU fishing, the global lack of transparency, traceability, and enforcement continues to allow IUU product to enter the U.S. market.

\subsection{Seafood nutrition and human health}

Unlike land-based sources of animal protein, the seafood sector is characterized by a tremendous diversity of species and production methods. As such, there is substantial variability in the nutritional profiles and relative health benefits and risks of different species within the seafood category. Likewise, there is just as much variability in the environmental performance of seafood and in some cases, how and where a product is produced, can influence the associated health benefits and risks (e.g., antibiotic use, location of catch and/or production relative to wastewater treatment facilities, agricultural run-off, etc.). Recognizing that the environmental conditions in which seafood is produced can play a role in its nutritional value, it is critical that the health benefits and risks associated with seafood consumption not be evaluated in isolation and that nutritional guidance be coupled with an understanding of the specific production methods and environmental conditions associated with different seafood choices.

\footnotetext{
75 U.S. Department of State. (2016). Trafficking in Persons Report 2016 (U.S. Department of State, Office to Monitor and Combat Trafficking in Persons, 2016). www.state.gov/j/tip/rls/tiprpt/2016/.

${ }^{76}$ Opal, Charlotte. (2019). Framework for Social Responsibility in the Seafood Sector. Certification and Ratings Collaboration.

${ }^{77}$ Lewis SG, Alifano A, Boyle M, Mangel M. Chapter 18-Human Rights and the Sustainability of Fisheries. In: Levin PS, Poe MR, editors. Conservation for the Anthropocene Ocean. Academic Press; 2017. pp. 379-396.

${ }^{78}$ World Wildlife Fund (2016). An Analysis of the Impact of IUU Imports on U.S. Fishermen.

79 ibid.
} 


\subsubsection{Health and nutritional benefits}

Government authorities and health care providers have long touted the nutritional benefits of fish and shellfish, recommending seafood as a healthier alternative to many land-based sources of animal protein. In fact, the USDA 2015-2020 Dietary Guidelines recommend a varied diet that includes eight ounces of seafood per week. ${ }^{80}$ While the nutritional profiles of seafood vary by species, seafood as a category is generally considered a nutrient-dense source of lean protein and omega-3 fatty acids.

\section{$0 \quad$ Nutrient value}

Fish are a source of important vitamins including vitamin D, vitamin B12, selenium, and vitamin B2 (riboflavin). Fish are also rich in calcium and phosphorous, as well as a source of minerals including iron, zinc, iodine, magnesium, and potassium. Notably, the heme iron found in fish is more bioavailable ${ }^{81}$ than the non-heme iron found in plant sources. ${ }^{82}$

\section{$0 \quad$ Omega-3 fatty acids}

Oily fish like salmon, mackerel, herring, lake trout, sardines, and albacore tuna are high in omega-3 fatty acids, specifically EPA (eicosapentaenoic acid) and DHA (docosahexaenoic acid), which evidence shows provide several health benefits. Among other things omega-3 fatty acids: help maintain cardiovascular health by regulating blood clotting and vessel constriction; support prenatal and postnatal neurological development; may reduce tissue inflammation and alleviate the symptoms of rheumatoid arthritis; and may reduce the risk of stroke, depression, Alzheimer's disease, and other chronic conditions. ${ }^{83} 84$

\subsubsection{Health and nutritional risks}

Despite its nutritional attributes, seafood consumption comes with some risk, which can vary with an individual's age, life stage, and history, and relates to the species, location and production method of the seafood product. Mercury contamination in seafood is one of the higher profile risks associated with seafood consumption but other additives and environmental contaminants including metals, industrial chemicals, pesticides, plastics, and antibiotics pose varying degrees of risk to seafood consumers. Indeed, a March 2020 import alert published by the U.S. Food and Drug Administration (FDA) warned that "[t]here has been an extensive commercialization and an increased consumption rate of aquaculture seafood products. As this industry grows, the use of unapproved new animal drugs and the misuse of approved new animal drugs in seafood raised through aquaculture also grows. The use of unapproved new animal drugs will have an impact on the safety of aquaculture products for consumers." ${ }^{85}$ Nevertheless, the risks of seafood consumption are neither limited to imports, nor are they confined to farmed fish and shellfish.

\section{$0 \quad$ Mercury}

Driven by mining and the burning of fossil fuels, the amount of anthropogenic mercury in the upper layer (down to $100 \mathrm{~m}$ depth) of the world's oceans has tripled since the beginning of the Industrial Revolution. ${ }^{86}$ Bacteria convert mercury into highly toxic methylmercury that is then absorbed by phytoplankton and bio-accumulates

\footnotetext{
80 U.S. Department of Health and Human Services and U.S. Department of Agriculture. (2015). 2015-2020 Dietary Guidelines for Americans. 8th Edition.

${ }^{81}$ Note: Bioavailable: the proportion of a nutrient that is absorbed from the diet and used for normal body functions.

82 U.S. Department of Health and Human Services and U.S. Department of Agriculture (2015).

${ }^{83}$ Raji, C.A., Erikson, K.I., Lopez, O., Kuller, L.H., Gach, H.M., Thompson, P.M., Riverol, M., Becker, J.T. (2014). Regular fish consumption and age-related brain gray matter loss. Am J. of Prev Med.; 47(4):444-51

${ }^{84}$ Mozaffarian D., Rimm E.B. Fish intake, contaminants, and human health: evaluating the risks and the benefits. JAMA. 2006; $296: 1885-99$.

${ }^{85}$ U.S. Food and Drug Administration. Import Alert 16-124. March 4, 2020.

${ }^{86}$ Lamborg, C., Hammerschmidt, C., Bowman, K. et al. (2014). A global ocean inventory of anthropogenic mercury based on water column measurements. Nature 512, 65-68. doi:10.1038/nature13563
} 
at higher trophic levels such that species including tuna, swordfish and sharks, among others, have mercury concentrations that are ten million times higher than the surrounding seawater. ${ }^{87}$ People who consume seafood contaminated with methylmercury are at risk of serious health problems as mercury can have toxic effects on the nervous, digestive and immune systems, and compromise the lungs, kidneys, skin, and eyes. Mercury poses a particular threat to the development of children in utero and in early life, and has been classified by the U.S. Environmental Protection Agency (EPA) and FDA as well as the World Health Organization as a major public health concern. ${ }^{88,89}$ Compounding this existing risk is new research that shows that the ocean's capacity to sequester mercury in the deep water is limited, ${ }^{90}$ and human society is projected to emit as much mercury in the next 50 years as it did in the last 150 years. ${ }^{91}$ As mercury emissions increase, more mercury will be found in shallower waters, which will increase mercury levels in seafood species, elevating the risk of human exposure. Studies have also found that mercury levels compromise the reproductive health and fertility of some fish and birds. ${ }^{92,93}$

\section{$0 \quad$ Pesticides and fertilizers}

Modern synthetic pesticides have been in use since the 1940s and now over a billion pounds of pesticides are used in the U.S. each year. While there are some benefits to the application of pesticides (e.g., control of invasive species, efficient food production, prevention of spread of insect-borne diseases, etc.), their use is not without risk or consequence. Pesticides are used both in terrestrial agriculture as well as some aquaculture operations. The impacts of pesticides on marine species and ecosystems can have both direct and indirect effects on human health. For example, the chemical malachite green, while banned for use in aquaculture in the U.S., Canada and European Union, is still used illegally in the U.S. and in other countries as a parasiticide/fungicide to prevent fungal attacks, protozoan infections and other diseases. ${ }^{94}$ Malachite green is believed to be toxic, mutagenic, and carcinogenic in animals, however there has been limited testing of domestic and imported seafood, including salmon to determine the presence of this chemical. ${ }^{95}$

Meanwhile, other agricultural pollutants, like fertilizer as well as wastewater run-offs, can cause eutrophication leading to anoxic conditions and harmful algal blooms (HABs) in nearby water bodies. HABs are characterized by high concentrations of toxic dinoflagellates that can bio- accumulate up the food chain reaching toxic levels that can lead to illness and, in some cases, mortality in humans and wildlife that consume affected species (Table 3). ${ }^{96}$

\footnotetext{
${ }^{87}$ ibid.

${ }^{88}$ Note: The U.S. Food and Drug Administration (FDA) and the U.S. Environmental Protection Agency (EPA) provide joint guidance regarding seafood consumption for women who are pregnant or breastfeeding and young children. See the FDA and EPA websites www.FDA.gov/fishadvice; www.EPA.gov/fishadvice.

${ }^{89}$ World Health Organization (2017). Mercury and Health Fact Sheet. https://www.who.int/news-room/fact-sheets/detail/mercury-and-health

${ }_{90}^{90}$ Lamborg, C., Hammerschmidt, C., Bowman, K. et al., 65-68

${ }^{91}$ ibid.

${ }^{92}$ Evers, D.C., Savoy, L.J., DeSorbo, C.R. et al. (2008). Adverse effects from environmental mercury loads on breeding common loons. Ecotoxicology 17 : 69.

${ }_{93}^{93}$ Crump, K.L. and Trudeau, V.L., (2009). Mercury-induced reproductive impairment in fish. Environmental Toxicology and Chemistry 28, $2009: 895-907$.

${ }_{94}^{4}$ U.S. Food and Drug Administration (2004). Laboratory Information Bulletin (LIB) 4333: Leucomalachite Green in Salmon.

https://www.fda.gov/food/laboratory-methods-food/laboratory-information-bulletin-lib-4333-leucomalachite-green-salmon

${ }_{95}^{5}$ Sudová, E., Machova, J., Svobodová, Z., and Veselý, T. (2007). Negative effects of malachite green and possibilities of its replacement in the treatment of fish eggs and fish: a review. Veterinarni Medicina, 52, 2007 (12): 527-539

${ }^{96}$ Marques, A., Nunes, M.L., Moore, S.K., and Strom, M.S. (2010). Climate change and seafood safety: Human health implications. Food Research International 43 (2010) 1766-1779
} 
Table 3. Summary of common illnesses caused by toxic marine harmful algal blooms (HABs), symptoms, toxins, associated HAB species. ${ }^{97}$

\begin{tabular}{|c|c|c|c|}
\hline Illness & Toxin(s) & Species & Symptoms \\
\hline Ciguatera fish poisoning (CFP) & Ciguatoxins & Gambierdiscus spp. ${ }^{\mathrm{b}}$ & $\begin{array}{l}\text { Nausea, vomiting, diarrhea, numbness of the mouth and } \\
\text { extremities, rash, and reversal of temperature sensation. } \\
\text { Neurological symptoms may persist for several months }\end{array}$ \\
\hline Paralytic shellfish poisoning (PSP) & Saxitoxin and its derivatives & $\begin{array}{l}\text { Alexandrium spp. } \\
\text { Pyrodinium spp. } \\
\text { Gymnodinium spp. }\end{array}$ & $\begin{array}{l}\text { Numbness and tingling of the lips, mouth, face and neck, } \\
\text { nausea, and vomiting. Severe cases result in paralysis of the } \\
\text { muscles of the chest and abdomen possibly leading to death }\end{array}$ \\
\hline Amnesic shellfish poisoning (ASP) & Domoic acid & ${ }^{a}$ Pseudo-nitzschia spp. & $\begin{array}{l}\text { Nausea, vomiting, diarrhea, headache, dizziness, confusion, } \\
\text { disorientation, short-term memory deficits, and motor } \\
\text { weakness. Severe cases result in seizures, cardiac } \\
\text { arrhythmias, coma, and possibly death }\end{array}$ \\
\hline $\begin{array}{l}\text { Azaspiracid shellfish poisoning } \\
\text { (AZP) }\end{array}$ & Azaspiracid and its derivatives & Protoperidinium spp. & Nausea, vomiting, severe diarrhea, and stomach cramps \\
\hline Diarrhetic shellfish poisoning (DSP) & Okadaic acid and its derivatives & $\begin{array}{l}\text { Dinophysis spp. } \\
\text { Prorocentrum spp. }\end{array}$ & Nausea, vomiting, severe diarrhea, and stomach cramps \\
\hline $\begin{array}{l}\text { Neurotoxic shellfish poisoning } \\
\text { (NSP) }\end{array}$ & Brevetoxins & Karenia spp. & $\begin{array}{l}\text { Nausea, temperature sensation reversals, muscle weakness, } \\
\text { and vertigo }\end{array}$ \\
\hline
\end{tabular}

${ }^{\text {a }}$ Denotes the only diatom group in the table.

b The remaining species are dinoflagellates, with the benthic members.

Prior to being banned in 1979, PCBs were used in many industrial and commercial applications including electrical, heat transfer and hydraulic equipment, pigments and dyes, and plasticizers. PCBs are highly toxic industrial compounds that accumulate in the sediments of marine, coastal, and aquatic environments from which they can enter the food chain and become concentrated in the fatty tissue of fish and other animals. Human exposure to PCBs can occur via continued consumption of fish contaminated with PCBs. In addition to PCBs being "probable human carcinogens," the EPA cautions that PCBs can cause a variety of other adverse health effects including compromising the function of the immune system, reproductive system, endocrine system, and nervous system. While PCBs are no longer manufactured in the U.S., they are slow to break down making them a continued health risk to fish, wildlife, and humans. ${ }^{98}$

\section{o $\quad$ Antibiotics}

Antibiotics are commonly used in aquaculture production to treat and prevent disease; however, their use can also contribute to the development of antibiotic-resistant bacteria that pose risks to human health. A metaanalysis of studies on antibiotics and seafood found that antibiotic-resistant bacteria in seafood has grown more than eight-fold in the past three decades. A parallel study in 2014 by researchers at Arizona State University analyzed 27 samples of seafood from 11 countries bought from stores in Arizona and California. The species included five of the top ten most consumed types of seafood in the U.S.: shrimp, tilapia, catfish, swai (pangasius), and Atlantic salmon. Researchers found detectable amounts of five antibiotics in the seafood samples. ${ }^{99}$ While farmed seafood is far more likely to contain antibiotics, wild fisheries are also susceptible, particularly if contaminated by water run off with antibiotic residues. Experts caution that even antibiotics present at levels that are well below regulatory limits still can promote the emergence of drug resistant microorganisms. ${ }^{100}$

\footnotetext{
${ }^{97}$ ibid.

${ }_{98}$ U.S. Environmental Protection Agency. (n.d.) Learn about Polychlorinated Biphenyls (PCBs). https://www.epa.gov/pcbs/learn-about-polychlorinatedbiphenyls-pcbs\#what

${ }^{99}$ Done, H. \& Halden, R. (2014). Reconnaissance of 47 Antibiotics and Associated Microbial Risks in Seafood Sold in the United States. Journal of Hazardous Materials. 282. 10.1016/j.jhazmat.2014.08.075.

100 ibid.
} 
o Allergens

Seafood allergies are the most common food allergy in adults and among the six most prevalent food allergies in young children. ${ }^{101} 102$ A 2004 study revealed that six percent of U.S. households include individuals with a seafood allergy. ${ }^{103}$ Allergic reactions to certain proteins in seafood can cause severe skin reactions, trigger asthma attacks, and/or lead to life-threatening anaphylaxis. Salmon, tuna, catfish, and cod were the fish that most commonly caused reactions, while shrimp was the most common type of allergy-inducing shellfish.

\section{o Micro-plastics}

An estimated eight million metric tons of plastics enter the oceans annually, ${ }^{104}$ and conservative estimates suggest 5.25 trillion plastic particles currently circulate in ocean surface waters. ${ }^{105}$ Because of this widespread contamination, micro-plastics are routinely ingested by marine fish and wildlife quickly making their way into the food chain bio-accumulating in different marine and aquatic organisms. ${ }^{106}$ Since micro-plastics are associated with chemicals from manufacturing, researchers are concerned about the potential physical and chemical toxicity. While evidence regarding micro-plastic toxicity and epidemiology is still emerging, researchers caution that the current dietary guidelines regarding seafood consumption may be misguided and the current state of the science suggests that greater research into and awareness of the health implications of microplastic-contaminated seafood could influence consumption. ${ }^{107}$

\subsection{Plant-Based Seafood}

\subsection{Plant-based seafood market and industry trends}

Plant-based food alternatives have been on the market for decades, however the category is rapidly evolving and diversifying. The consumer trend towards flexitarian, vegan, and vegetarian diets is accelerating the development and production of plant-based proteins, including those used for seafood substitutes. While many meat and seafood substitutes are still based on soy or wheat gluten protein, new products are emerging with alternative proteins, nutritional additives, and flavor enhancers. Plant-based meat alternatives such as Tofurkey and Boca Burgers, which largely targeted vegetarian and vegan consumers by creating plant-based products that looked like conventional meat burgers or poultry products, opened the door for the latest generation of plantbased products. This new generation of products distinguish themselves from their predecessors by attempting to replicate not just the look, but the taste and texture of traditional animal-based meat products to appeal to more omnivorous consumers (aka "flexitarians").

According to OpenTable, reviews mentioning plant-based food increased by 136 percent between 2017 and 2019. ${ }^{108}$ Likewise, the U.S. retail sector has seen a surge in plant-based purchases, with sales of plant-based foods growing by 20 percent in 2018, according to Nielsen data commissioned by the Plant Based Foods Association. ${ }^{109}$ Indeed, the growth of the plant-based sector is ten times greater than average growth of all food

\footnotetext{
${ }^{101}$ Sicherer, S.H., Sampson, H.A. (2018). Food allergy: A review and update on epidemiology, pathogenesis, diagnosis, prevention, and management. J Allergy Clin Immunol; 141:41.

${ }^{102}$ Gupta R.S., Springston, E.E., Warrier, M.R., et al. (2011). The prevalence, severity, and distribution of childhood food allergy in the United States. Pediatrics 2011; 128:e9.

${ }^{103}$ Sicherer, S., Muñoz-Furlong, A., Sampson, H. (2004). Prevalence of seafood allergy in the United States determined by a random telephone survey. The Journal of allergy and clinical immunology. 114. 159-65. 10.1016/j.jaci.2004.04.018.

${ }^{104}$ Gourmelon G. (2015) Global plastic production rises, recycling lags. Vital Signs.

${ }^{105}$ Eriksen, M., Lebreton, L.C.M., Carson, H.S., Thiel, M., Moore, C.J, Borerro, J.C., et al. (2014) Plastic Pollution in the World's Oceans: More than 5 Trillion Plastic Pieces Weighing over 250,000 Tons Afloat at Sea. PLoS One. 2014;9(12):e111913. doi: 10.1371/journal.pone.0111913.

${ }^{106}$ Ivar do Su, J.A., Costa, M.F. (2014) The present and future of microplastic pollution in the marine environment. Environ Pollut. 2014;185: 352-364.

${ }^{107}$ Smith, M., Love, D.C., Rochman, C.M., Neff, R.A. (2018). Microplastics in Seafood and the Implications for Human Health. Curr Environ Health Rep. 2018;5(3):375-386. doi:10.1007/s40572-018-0206-z

108 Open Table. (2019). What was on diner's plates in 2019? https://blog.opentable.com/year-in-review-2019/

${ }^{109}$ Plant Based Foods Association. (n.d.) Retail Sales Data 2018. https://plantbasedfoods.org/marketplace/retail-sales-data-2018/
} 
(Figure 3). ${ }^{110}$ A well-publicized example of this is Beyond Meat's meteoric rise with share value up over 120 percent since its May 2019 initial public offering and an estimated worth of USD 8.6 billion as of September 2019. Meanwhile, the plant-based food industry's projected worth in the next decade is USD 140 billion, potentially capturing ten percent of the USD 1.4 trillion global meat industry. ${ }^{111}$

Figure 3. Total Growth of All Plant-Based Food by Category ${ }^{112}$

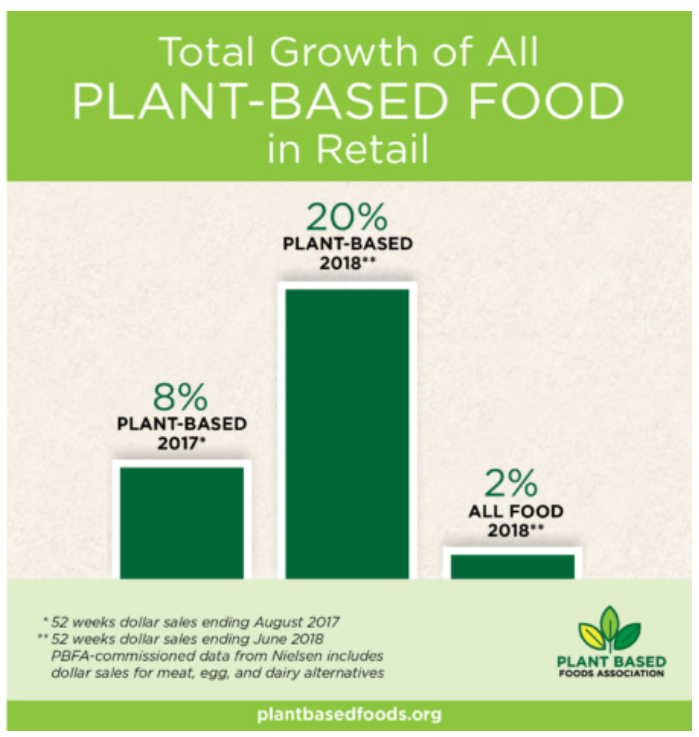

Figure 4. Growth of Plant-based Alternatives in Retail ${ }^{113}$

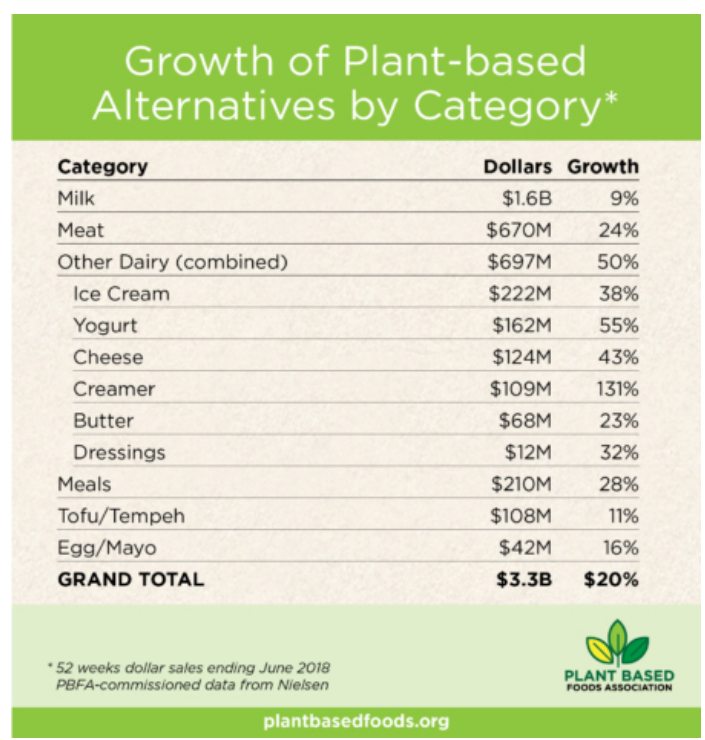

Given the claims by advocates that plant-based proteins are more humane, sustainable, and potentially healthier than their animal-based counterparts, analysts at Barclays Investment Bank argue that "there is a bigger market opportunity for plant-based (and maybe even lab-based) protein than perhaps was argued for electric vehicles ten years ago." ${ }^{114}$ Indeed, some larger U.S. food producers, like Tyson Foods and General Mills, are taking note and investing in plant-based protein alternatives, while others including Bumble Bee Foods, are partnering with smaller plant-based food companies to diversify their own portfolios and carve out a foothold in this growing market.

In the case of plant-based seafood alternatives, many producers are looking to the recent success of plant-based meat and developing products that not only mimic the taste and texture of conventional seafood, but improve upon the nutritional profile of seafood. They are also counting on the recent surge in the plant-based foods sector to pave the way for investor interest and consumer demand for plant-based seafood (Figure 4). If the recent investment of USD 32 million by General Mills in Good Catch is any indication, plant-based seafood is poised to become a mainstream alternative to traditional seafood. ${ }^{115}$

\subsection{Environmental costs and benefits of plant-based seafood}

The environmental footprint of plant-based seafood alternatives is a function of many variables including the cultivation and production of the product's ingredients, processing, packaging, and transportation. That said, plant-based seafood alternatives are not monolithic. Indeed, there is a diverse range of processes and products,

\footnotetext{
110 ibid.

${ }^{111}$ Barclays Investment Bank (2019 August 19). Carving up the alternative meat market. https://www.investmentbank.barclays.com/our-insights/carvingup-the-alternative-meat-market.html

112 ibid.

113 Plant Based Foods Association. (n.d.) Retail Sales Data 2018.

${ }^{114}$ Barclays Investment Bank (19 August 2019). Carving up the alternative meat market.

115 Pietsch, Bryan (26 January 2020). A plant-based seafood startup just got a big boost from one of America's biggest and oldest food companies. Business Insider.
} 
and the ingredients that producers use to create plant-based seafood including, among other things, soy, wheat, legumes, tomatoes, eggplant, seaweed and konjac, are highly varied (Table 4). Even so, soy and wheat are among the leading ingredients for many plant-based proteins while seaweed extract, a nutritional and flavoring additive, provides many products with more of a seafood taste.

Table 4. Plant-Based Seafood Alternatives: Primary Ingredients

\begin{tabular}{|c|c|c|}
\hline Company & Product & Primary Ingredients \\
\hline \multirow{3}{*}{ Good Catch } & Tuna & \multirow{3}{*}{$\begin{array}{c}\text { Legume blend (peas, chickpeas, } \\
\text { lentils, soy fava beans, and navy } \\
\text { beans) }\end{array}$} \\
\hline & Fish Cakes \& Fish Burgers & \\
\hline & Crab Cakes & \\
\hline \multirow{2}{*}{ New Wave Foods } & \multirow{2}{*}{ Shrimp } & Seaweed \\
\hline & & Soy \\
\hline \multirow{2}{*}{ Ocean Hugger Foods } & Tuna (“Ahimi") & Tomato \\
\hline & Eel (“Unami”) & Eggplant \\
\hline \multirow{3}{*}{ All Vegetarian, Inc } & Shrimp & Vegetable Gum \& Starch \\
\hline & Tuna & Soy \& Wheat \\
\hline & White Fish & Soy \& Seaweed \\
\hline Loma Linda & Tuna & Soy, Wheat \& Seaweed \\
\hline Fry's Family Food & Shrimp & Soy \& Wheat \\
\hline \multirow{6}{*}{ Sophie's Kitchen } & Crab cakes & \multirow{6}{*}{ Konjac, Pea Protein, \& Seaweed } \\
\hline & Shrimp & \\
\hline & Lobster & \\
\hline & Tuna & \\
\hline & White Fish & \\
\hline & Salmon & \\
\hline \multirow[t]{2}{*}{ The Van Cleve Seafood Co. } & Crab (“Crabless Cakes”) & $\begin{array}{c}\text { Artichokes, Hearts of Palm \& } \\
\text { Kelp }\end{array}$ \\
\hline & Shrimp & Konjac \\
\hline Jinka & Tuna & Soy, Wheat \& Algae Oil \\
\hline
\end{tabular}

\subsubsection{Plant Agriculture}

As with the production of any product, plant-based agriculture is not without its impacts. Even so, the magnitude of environmental impact is highly variable between agricultural product categories and is influenced by, among other things, the species being farmed, geography, and production/harvest method. ${ }^{116}$ This variability applies even within specific product categories, making it difficult to generalize across a class of crop (e.g., soy, wheat, etc.). Still, the sustainability of plant-based agriculture can be evaluated relative to different environmental impact categories that are not dissimilar to aquaculture. These include: eutrophication associated with fertilizer runoff; pesticide use and waste; loss of habitat and biodiversity; changes in land use and disturbance; water use; energy use; heavy metal soil release; and greenhouse gas emissions associated with machinery operation, transportation, and chemical application in agricultural crop production. ${ }^{117} 118$

\footnotetext{
${ }^{116}$ O'Donnell, BG. (2008). Life Cycle Assessment of American Wheat: Analysis of Regional Variations in Production and Transportation (MS Thesis, University of Washington). http://depts.washington.edu/sctlctr/sites/default/files/research_student_thesis/ODonnellBThesis.pdf

${ }_{117}$ Tilman, D., Fargione J., Wolff B., D'Antonio C., Dobson A., Howarth R., Schindler D., Schlesinger W.H., Simberloff D., Swackhamer D. (2001): Forecasting Agriculturally Driven Global Environmental Change. Science 292, 281- 284

${ }_{118}$ Tilman, D. (1999): Colloquium Paper Global environmental impacts of agricultural expansion: The need for sustainable and efficient practices. Proc Natl Acad Sci US A 96, 5995-6000
} 
Global biodiversity loss is undermining food and economic security for millions of people worldwide and agriculture has become one of the largest contributors to biodiversity loss. ${ }^{119}$ Indeed, of the 30 thousand species listed as threatened with extinction on the IUCN Red List, agriculture is listed as a threat for over 26 thousand species. ${ }^{120}$ That said, biodiversity and agriculture are very much inter-related as agriculture depends on the ecosystem services provided by biodiversity and sustainable agricultural practices can help promote and enhance biodiversity. In addition to supporting soil and water conservation, pollination, soil fertility, and biota, genetic diversity provides species with the ability to adapt and evolve in the face of a changing climate. Whether strengthening tolerance to frost, high temperature, drought and flooding, or increasing resistance to diseases, pests and parasites, agricultural practices that support biodiversity can enhance the productivity and resilience of plant agriculture.

While industrial-scale farming represents a significant threat to biodiversity globally, small-holder crop farming poses an even greater threat in terms of the number of species threatened. ${ }^{121}$ New research in the Amazon demonstrates that while small-holder agriculture can support high biodiversity at a small spatial scale, the expansion of small-holder farms in biodiverse areas like the Amazon can have devastating broad-scale effects on biodiversity. ${ }^{122}$ These findings have implications for plant-based producers in terms of product sourcing. While larger-scale agricultural producers can offer lower costs, there is an opportunity for the plant-based industry to expand their mandate around corporate social responsibility by engaging with third parties like Fair Trade USA and similar organizations that are working to engage small holders to improve the sustainability of their practices and access higher value markets for their products.

\section{$0 \quad$ Land use}

As natural landscapes are being destroyed and converted into intensely managed production systems, erosion, loss of organic carbon, nutrient imbalances, salinization, and pollutant contamination are further threatening biodiversity. ${ }^{123}$ However, the majority (77 percent) of global agricultural land area is directed towards livestock farming while crop production accounts for 63 percent of the global protein supply and 83 percent of the global calorie supply. ${ }^{124}$ This suggests that transitioning from land-based sources of meat to plant-based diets could reduce agricultural pressure on forest and grasslands around the world, provided that land currently used to support livestock production can be repurposed to crops for alternative meat and seafood production. Whether the same is true when comparing aquaculture to plant agriculture is more nuanced and largely depends on the products being compared and the framework for evaluating land use impacts.

A comparison between the land use footprint of several plant-based seafood ingredients and different aquaculture products yields different results depending on whether you compare products based on mass (the land use to produce one kilogram of food product), protein, or calories. For example, tomatoes are a low impact crop from a land use perspective when compared with other products in terms of mass, however tomatoes are a high-impact product when evaluating land use relative to protein production (Figures 5 and 6). ${ }^{125}$ That is, it takes a lot more land to get the same amount of protein out of tomatoes than peas or soybeans. The reverse is

\footnotetext{
${ }^{119}$ FAO. (2019). The State of the World's Biodiversity for Food and Agriculture, J. Bélanger \& D. Pilling (eds.). FAO Commission on Genetic Resources for Food and Agriculture Assessments. Rome. 572 pp. (http://www.fao.org/3/CA3129EN/CA3129EN.pdf) Licence: CC BY-NC-SA 3.0 IGO.

120 IUCN Red List. (n.d.). https://www.iucnredlist.org/search/stats (visited January 2020)

121 ibid.

122 Jacob B. Socolar, J.B., Valderrama Sandoval, E.H., Wilcove, D.S. (2019). Overlooked biodiversity loss in tropical smallholder agriculture. Conservation Biology. DOI: $10.1111 /$ cobi.13344

${ }^{123}$ Dudley, N. \& Alexander, S. (2017). Agriculture and biodiversity: a review, Biodiversity, 18:2-3, 45-49, DOI: 10.1080/14888386.2017.1351892

124 Poore, J.\& Nemecek, T. (2018). Reducing food's environmental impacts through producers and consumers. Science, 260(6392), 987-992.

125 ibid.
} 
Can Plant- and Cell-Based Seafood Improve human and Planetary Health?

true for soybeans and farmed shrimp (prawns), which are considered medium impact products when evaluated in terms of mass but low impact products when assessed in terms of protein (Figures 5 and 6). ${ }^{126}$

Figure 5. Land use per kilogram of food product ${ }^{127}$

Land use per kilogram of food product

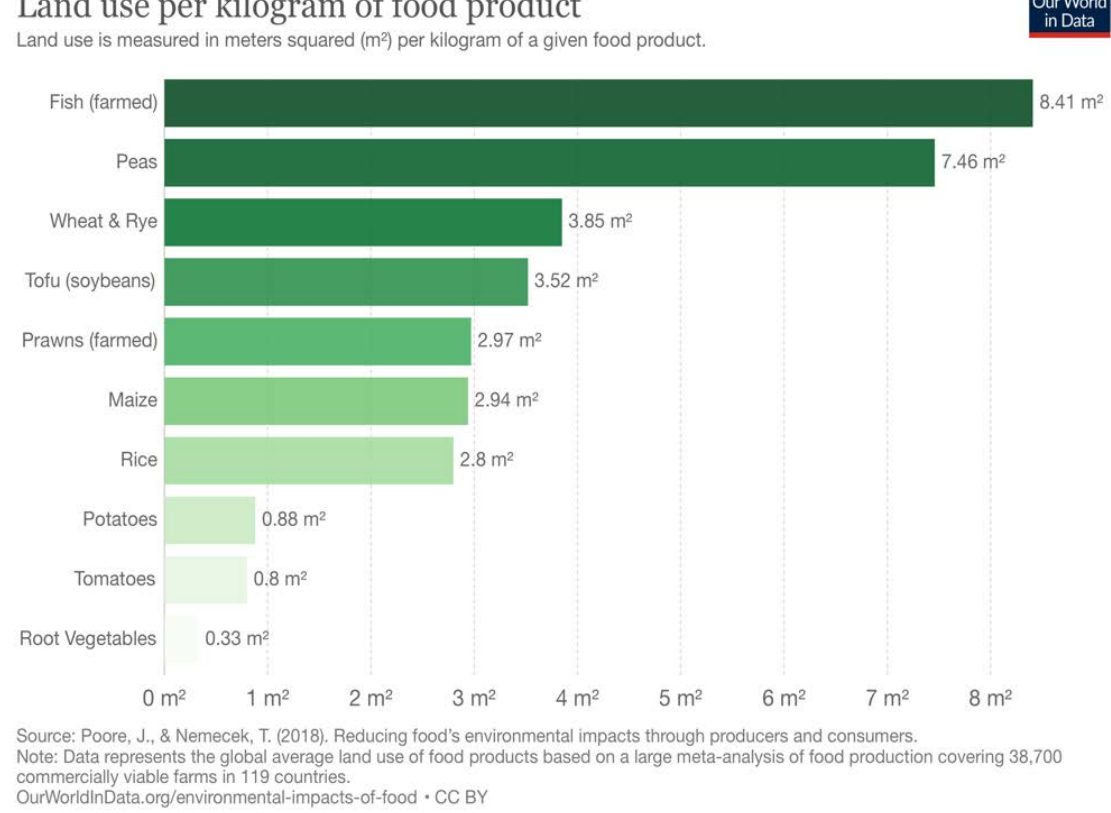

Figure 6. Land use per 100 grams of protein ${ }^{128}$

Land use per 100 grams of protein

Land use is measured in meters squared $\left(\mathrm{m}^{2}\right)$ per 100 grams of protein across various food products.

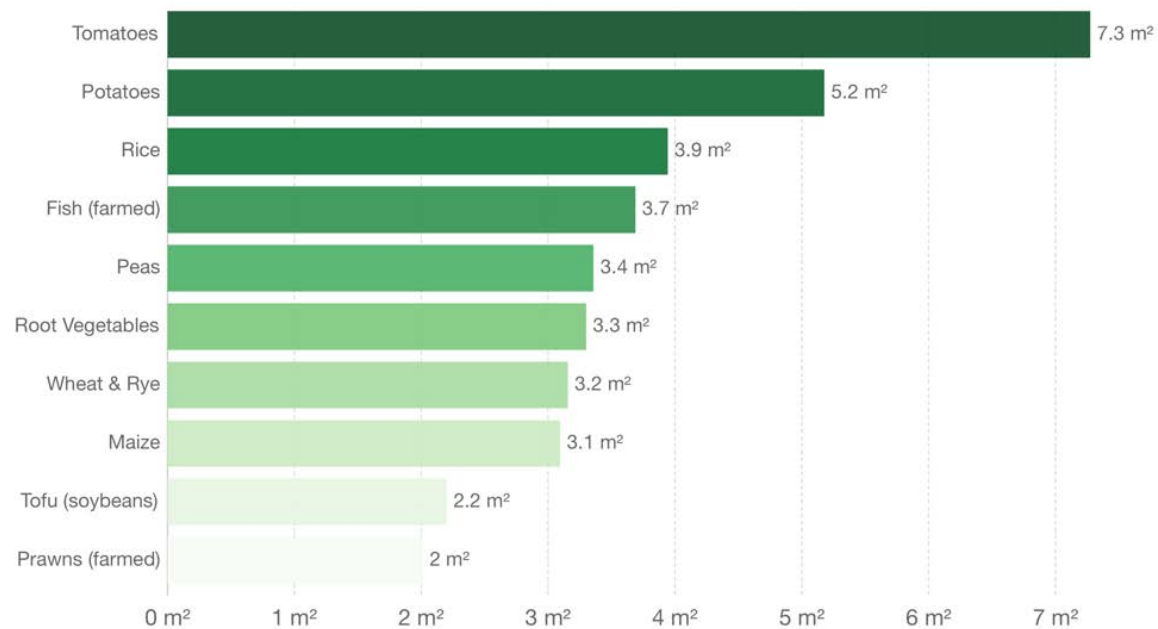

Source: Poore, J., \& Nemecek, T. (2018). Additional calculations by Our World in Data.

Note: Data represents the global average land use of food products based on a large meta-analysis of food production covering 38,700

OurWorldlnData.org/environmental-impacts-of-food · CC BY 


\section{0 $\quad$ Greenhouse gas emissions}

Greenhouse gas emissions from food production consist mainly of carbon dioxide $\left(\mathrm{CO}_{2}\right)$, nitrous oxide $\left(\mathrm{NO}_{2}\right)$, and methane $\left(\mathrm{CH}_{4}\right)$, which result primarily from agricultural practices, but emissions can vary significantly across and within categories of food. For instance, red meat is approximately 150 percent more GHG-intensive than chicken or fish, and meat products have larger carbon footprints per calorie than grain or vegetable products. ${ }^{129}$ This is because of the inefficient transformation of plant energy to animal energy, along with the methane released from manure management and enteric fermentation in ruminants. ${ }^{130}$ In general, $\mathrm{CO} 2$ emissions associated with most plant-based products are 10-50 times less than emissions associated with animal-based products (Figure 7). ${ }^{131}$

Figure 7. Food: greenhouse gas emissions across the supply chain ${ }^{132}$

\section{Food: greenhouse gas emissions across the supply chain}
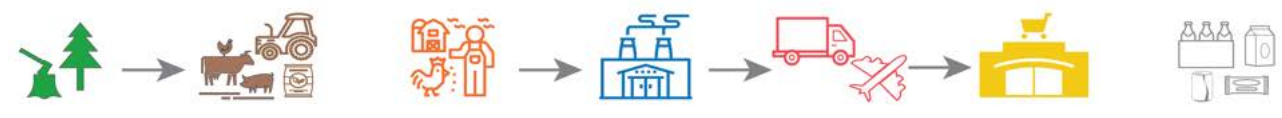

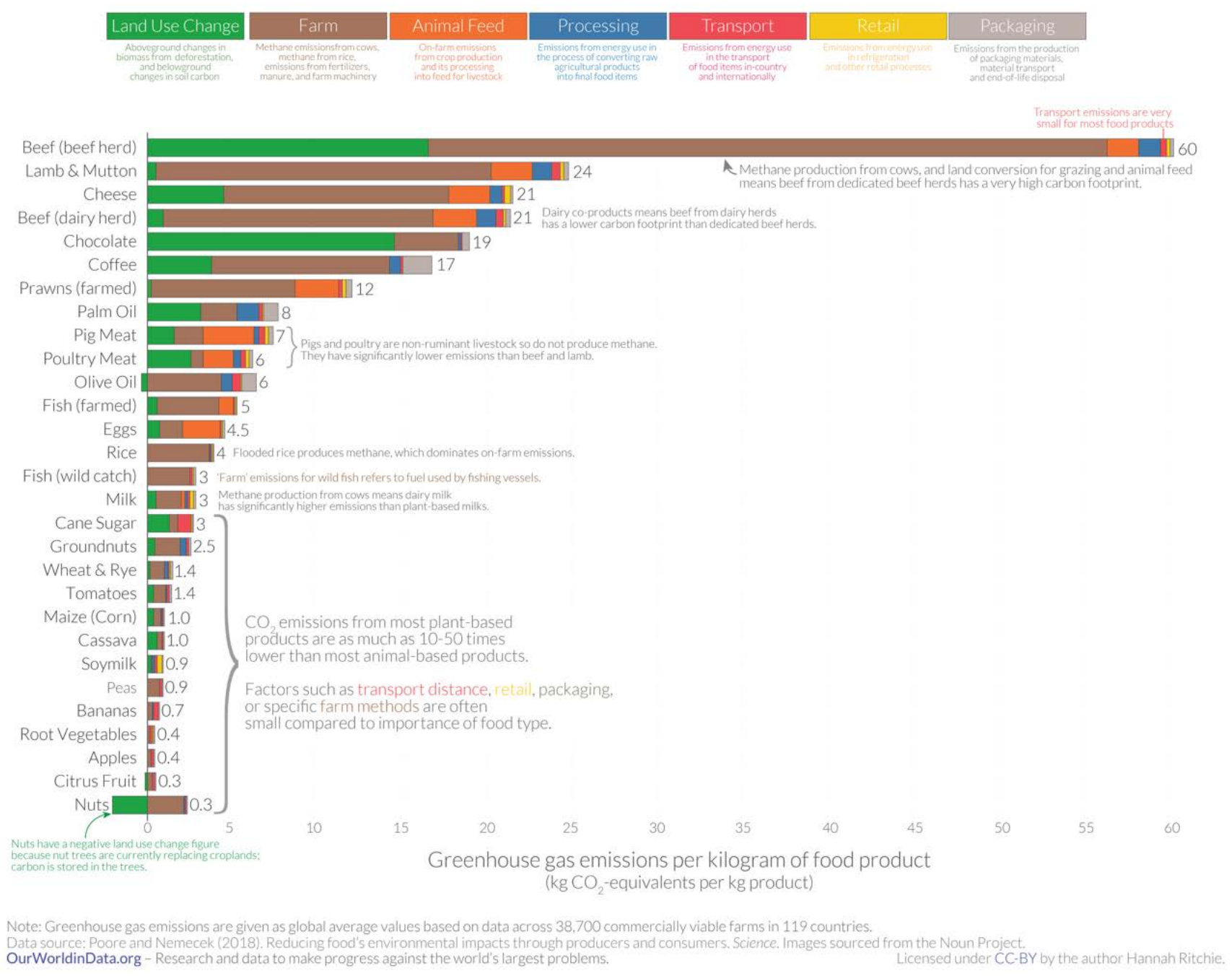

129 ibid.

${ }^{130}$ Weber, C. and H. Matthews. (2008). Food Miles and the Relative Climate Impacts of Food Choices in the United States. Environmental Science \& Technology, 42(10): 3508-3513.

${ }^{131}$ Poore \& Nemecek, 987-992

132 ibid. 
Plant-based food consumers are often looking for products that offer comparable nutritional profiles in terms of protein content to animal-based products. Thus, evaluating emissions relative to the amount of protein a product can yield can be a useful framework for producers and others to identify low carbon footprint ingredients that will also meet the consumer demand for protein. For instance, the relatively low protein content of tomatoes means that they will have significantly higher emissions per $100 \mathrm{~kg}$ of protein produced than farmed fish or crops such as peas, wheat and rye, maize (corn), and soybeans (Figure 8). ${ }^{133}$

\section{Figure 8. Greenhouse gas emissions per 100 grams of protein ${ }^{134}$}

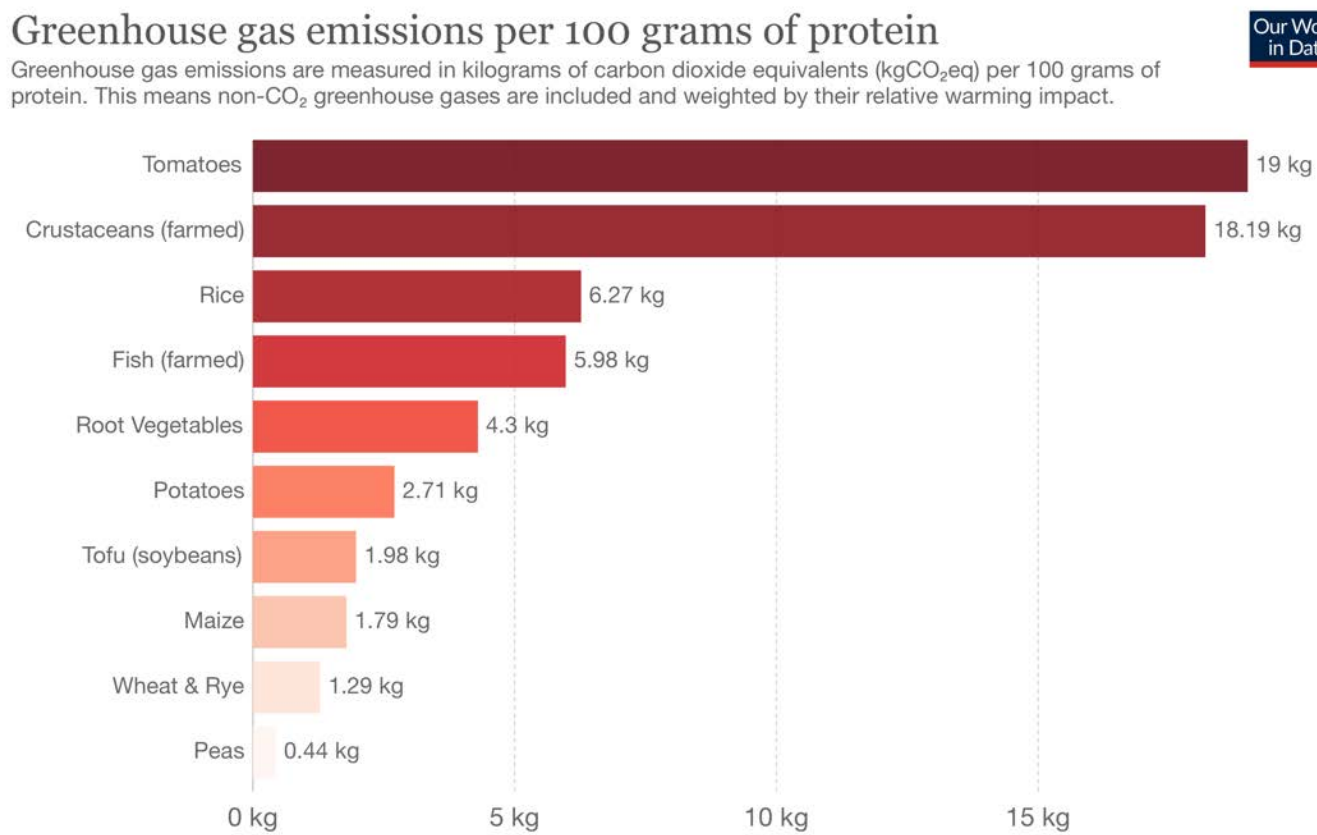

Source: Poore, J., \& Nemecek, T. (2018). Additional calculations by Our World in Data. Note: Data represents the global average greenhouse gas emissions of food products based on a large meta-analysis of food production

covering 38,700 commercially viable farms in 119 countries.
OurWorldlnData.org/environmental-impacts-of-food $\cdot$ CC BY

\section{o Eutrophication}

Agricultural production systems are a leading contributor to eutrophication of nearby and downstream waters. Nutrient loading from organic waste and fertilizer (nitrogen and phosphorous) run-off can degrade ecosystems contributing to harmful algal blooms and hypoxia in marine and aquatic environments. This can have devastating ecological and economic consequences. The estimated cost of damage from eutrophication in the U.S. alone is approximately 2.2 billion USD annually. ${ }^{135}$ Agricultural practices, including the application rates of fertilizer, can vary by individual species, as well as by location and can be influenced by soil types, available nutrients, precipitation, and temperature. ${ }^{136}{ }^{137}$ As such, it is difficult to generalize, however a macro-level comparison suggests that by unit weight, farm-raised seafood releases much higher levels of eutrophying nutrients than many crops that may be used for plant-based seafood production (Figure 9). ${ }^{138}$

\footnotetext{
133 ibid.

${ }^{134}$ ibid.

${ }^{135}$ Dodds, W. K. et al. Eutrophication of U.S. freshwaters: analysis of potential economic damages. Environmental Science and Technology 43, 12-19 (2009).

${ }^{136}$ Fernandez-Cornejo, J., Jans S. (1999): Pest Management in U.S. Agriculture. U.S. Dept. of Agriculture, Economic Research Service

137 O'Donnell, BG, “Life Cycle Assessment of American Wheat: Analysis of Regional Variations in Production and Transportation” (MS Thesis, University of Washington) 2008.

${ }^{138}$ Poore \& Nemecek, 987-992.
} 
Figure 9. Eutrophying emissions per kilogram of food product ${ }^{139}$

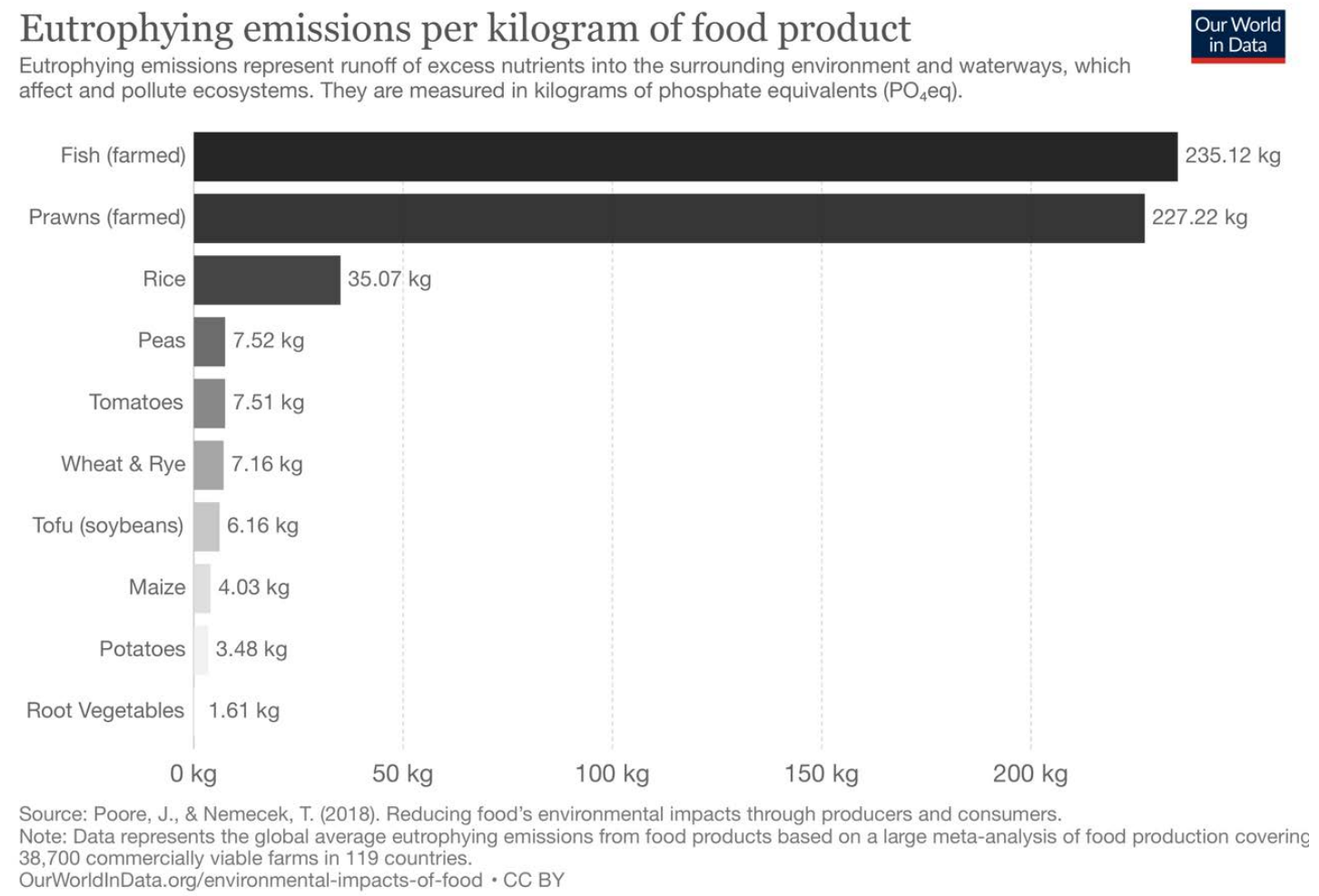

W Water use

The agricultural sector accounts for about 85 percent of global freshwater water consumption. ${ }^{140}$ However, within this sector, the water footprint and impact on freshwater resources of different agricultural products is highly variable. Likewise, in addition to the total volume of water used, the relative scarcity of water in a geography plays a role in determining the impact of various crops on water resources. In other words, where freshwater is relatively scarce, the impact of crop production on water resources is greater. For instance, when weighted relative to scarcity, global soy production has a lower impact in terms of water usage than wheat and rye, but as agricultural commodities, soy, wheat and rye all have less impact on water resources when compare with farmed fish and prawns (Figure 10). ${ }^{141}$

In addition to the water footprint associated with the production of plant-based food ingredients, the processing of those ingredients to create plant-based seafood products is water intensive. Indeed, some products flush the plants with water to remove distinctive tastes and smells and create a more neutral palate for flavors. In addition, the waste emerging from food processing facilities is typically diluted with grey water to make it safe for disposal and comply with local water pollution guidelines. To get a clear sense of the overall water footprint of plant-based foods relative to their conventional seafood counterparts, product-specific assessments that incorporate both production and processing are needed.

\footnotetext{
139 ibid.

${ }^{140}$ Mekonnen, M.M. and Hoekstra, A.Y. (2010) The green, blue and grey water footprint of crops and derived crop products, Value of Water Research Report Series No. 47, UNESCO-IHE, Delft, the Netherlands.

141 Poore \& Nemecek, 987-992
} 


\section{Figure 10. Scarcity-weighted water use per kilogram of food product ${ }^{142}$}

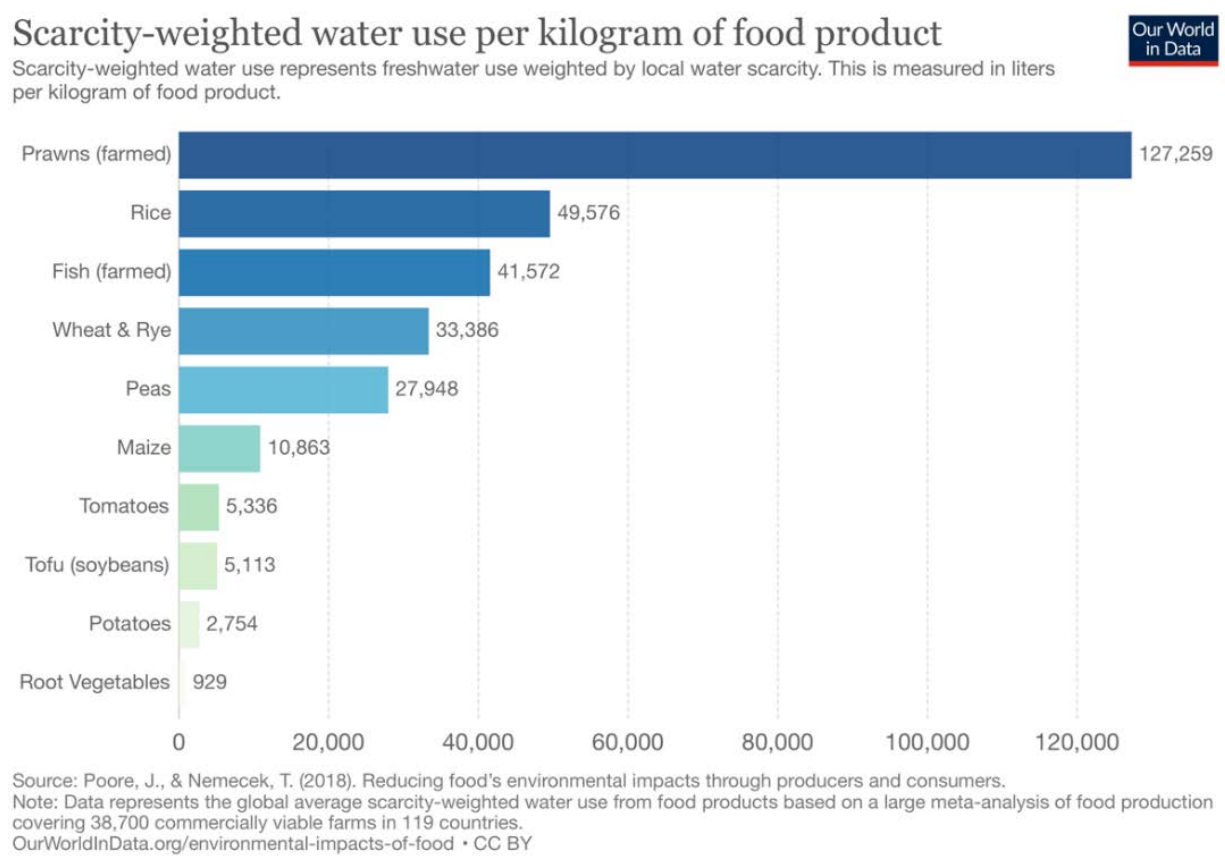

\subsubsection{Seaweed and Algae Production}

In addition to terrestrial crops, the plant-based seafood industry relies heavily on seaweed and algae oil to provide flavoring and nutritional benefits to their products. Seaweed cultivation, while not without impact, offers advantages both nutritionally and environmentally over terrestrial plant agriculture and other forms of conventional seafood. Protein derived from algae oil is nutritionally equivalent to soy protein, ${ }^{143}$ but can be produced without fuel, fertilizer, freshwater, or land. Expanding seaweed cultivation could provide ecosystem benefits including removing phosphorous and nitrogen from the environment, capturing and sequestering carbon, and water filtration (Table 5). ${ }^{144}$

Table 5: Ecosystem Services provided by Seaweed Cultivation ${ }^{145}$

TABLE 1. Extrapolated ecosystem services from 500 million tons (dry weight) of seaweeds.

\begin{tabular}{|c|c|c|}
\hline Ocean area required & $500,000 \mathrm{~km}^{2}$ & $\begin{array}{l}\text { Based on average annual yield of } 1,000 \text { dry tons } / \mathrm{km}^{2} \text { undert current best } \\
\text { practice. Equals } 0.03 \% \text { of the ocean surface area. }\end{array}$ \\
\hline $\begin{array}{l}\text { Protein for people } \\
\text { and animals }\end{array}$ & $50,000,000$ tons & $\begin{array}{l}\text { Assumes average protein content of } 10 \% \text { dry weight. Estimated value } \\
\$ 28 \text { billion. Could completely replace fishmeal in animal feeds. }\end{array}$ \\
\hline $\begin{array}{l}\text { Algal oil for people } \\
\text { and animals }\end{array}$ & $15,000,000$ tons & $\begin{array}{l}\text { Assumes average lipid content of } 3 \% \text { dry weight. Estimated value } \$ 23 \text { billion. } \\
\text { Could completely replace fish oil in animal feeds. }\end{array}$ \\
\hline Nitrogen removal & $10,000,000$ tons & $\begin{array}{l}\text { Assumes nitrogen content } 2 \% \text { of dry weight. Equals } 18 \% \text { of the nitrogen } \\
\text { added to oceans through fertilizer. }\end{array}$ \\
\hline $\begin{array}{l}\text { Phosphorous } \\
\text { removal }\end{array}$ & $1,000,000$ tons & $\begin{array}{l}\text { Assumes phosphorous content } 0.2 \% \text { of dry weight. Represents } 61 \% \text { of the } \\
\text { phosphorous input as fertilizer. }\end{array}$ \\
\hline Carbon assimilation & $135,000,000$ tons & $\begin{array}{l}\text { Assumes carbon content } 27 \% \text { of dry weight. Equals } 6 \% \text { of the carbon added } \\
\text { annually to oceans from greenhouse gas emissions. }\end{array}$ \\
\hline Bioenergy potential & $\begin{array}{l}1,250,000,000 \\
\text { MWH }\end{array}$ & $\begin{array}{l}\text { Assumes } 50 \% \text { carbohydrate content, converted to energy. Equals } 1 \% \text { of } \\
\text { annual global energy use. }\end{array}$ \\
\hline Land sparing & $1,000,000 \mathrm{~km}^{2}$ & Assumes 5 tons/ha average farm yield. Equals $6 \%$ of global cropland. \\
\hline Freshwater sparing & $500 \mathrm{~km}^{3}$ & $\begin{array}{l}\text { Assumes agricultural use averages } 1 \mathrm{~m}^{3} \text { water } / \mathrm{kg} \text { biomass. Equals } 14 \% \text { of } \\
\text { annual global freshwater withdrawals. }\end{array}$ \\
\hline
\end{tabular}

\footnotetext{
142 ibid.

${ }^{143}$ Bjerregaard, R. (n.d.). Seaweed Aquaculture for Food Security, Income Generation and Environmental Health in Tropical Developing Countries. World Bank Group, http://documents.worldbank.org/curated/en/947831469090666344/pdf/107147-WP-REVISED-Seaweed-Aquaculture-Web.pdf.

144 ibid.

145 ibid.
} 
Despite its many benefits, there are several potentially high-risk drivers of environmental change associated with seaweed cultivation. Seaweed cultivation can alter ecosystem balance and functioning by interfering with light, nutrient, and kinetic energy absorption. ${ }^{146}$ The latter can lead to large-scale changes in local hydrodynamics. ${ }^{147}$ Seaweed farming can also facilitate disease, parasites, and non-native species that could disrupt marine communities. ${ }^{148}$ Not unlike wild capture fisheries and aquaculture operations, the addition of artificial materials including vertical lines to anchor seaweed to the substrate poses risks of entanglement and mortality for marine megafauna, particularly vulnerable sea turtle and marine mammal populations. Likewise, discarded or lost materials (e.g., polypropylene rope) can turn into marine debris without adequate precautions and eventually degrade into micro-plastics contributing to pollution and making their way into the marine food web. As the demand for seaweed increases, it will be critical to implement measures to mitigate these potential impacts and promote models for sustainable seaweed cultivation.

\subsection{Socio-economic costs and benefits of plant-based seafood}

\subsubsection{Economic and food security}

According to a 2016 report by the Plant Based Foods Association, the plant-based industry provides over 60 thousand jobs and contributes USD 13.7 billion to the U.S. economy a year. ${ }^{149}$ Included in these sales figures are revenues from the industry itself as well as sales from suppliers and upstream companies. Given the increasing demand for plant-based foods, the industry is growing rapidly and, at the current rate of growth, it is projected that it will add more than two thousand jobs to the economy annually and generate USD 13.3 billion in tax revenues over the next ten years. ${ }^{150}$ What percentage of this growth is likely to be attributable to the burgeoning plant-based seafood sector is uncertain, but evidence suggests that growth in the sector as a whole is a net gain for the economy and employment in the United States.

As the global population increases, geopolitical uncertainty grows and climate change intensifies, the agricultural sector is becoming increasingly vulnerable. Indeed, the agricultural sector is particularly susceptible to climate variations including droughts, floods, and extreme temperatures that can contribute to resource scarcity, competition for resources (land, energy, water and nutrients) and increasing costs. Compounding these climate risks is a decrease in crop diversity and a disproportionate reliance on crops to produce biofuel and feed for animal agriculture and aquaculture rather than food for direct human consumption. ${ }^{151}$ Combined, these factors suggest that the current agricultural food system, without significant changes, poses substantial risks to global food security and economic security. If plant-based foods (seafood, meat, dairy, etc.) can secure a foothold in the global marketplace and shift some of the demand away from animal-based products, it could relieve some of the pressure on our current agricultural systems. Even so, to ensure a less vulnerable and more resilient system, there needs to be a broader shift towards more sustainable and regenerative agricultural practices and a greater diversity of crops available to plant-based producers to help mitigate these risks.

\subsubsection{Unfair and exploitative labor practices}

The agricultural sector, which supplies most of the ingredients for the plant-based food industry,

\footnotetext{
${ }^{146}$ Campbell, lona \& MacLeod, Adrian \& Sahlmann, Christian \& Neves, Luiza \& Jon, Funderud \& Øverland, Margareth \& Hughes, Adam \& Stanley, Michele. (2019). The Environmental Risks Associated with the Development of Seaweed Farming in Europe-Prioritizing Key Knowledge Gaps. Frontiers in Marine Science. 6. 10.3389/fmars.2019.00107.

147 ibid.

148 ibid.

${ }^{149}$ Plant Based Foods Association (2016). The Plant Based Foods Industry Contribution to the U.S. Economy. https://plantbasedfoods.org/wpcontent/uploads/2016/09/PBFA-Econ-Report-2016.pdf

${ }_{150}$ Plant Based Foods Association (2016). The Plant Based Foods Industry Contribution to the U.S. Economy

${ }^{151}$ FAO. (2017). Global database of GHG emissions related to feed crops: Methodology. Version 1. Livestock Environmental Assessment and Performance Partnership. FAO, Rome, Italy.
} 
employs approximately one billion people making up roughly one-third of the global workforce. ${ }^{152}$ However, the proportion of people working in agriculture is not evenly distributed throughout the world and there are dramatic differences between more developed and lesser developed countries. For example, in the Democratic Republic of the Congo, 65 percent of employed people work in agriculture. In the U.S., on the other hand, agriculture provides employment for only one percent of the employed workforce. ${ }^{153}$ As is the case with both fisheries and aquaculture, many agricultural workers are part of the industrialized food system focused on maximizing profits while minimizing costs. The workers themselves are often poor migrants lacking social and economic protections including access to collective bargaining to negotiate wages and working conditions. ${ }^{154} \mathrm{~A}$ 2018 United Nations report noted that many workers are regularly exposed to pesticides, spend long hours in extreme temperatures, and do not have adequate access to water. What's more, it is estimated that as many as 170 thousand are killed doing their jobs each year. ${ }^{155}$ In many parts of the world, there is a lack of strong governance capacity to enforce fair labor practices and ensure that the fundamental human rights of workers are protected. As such, it's incumbent upon the private sector to leverage their purchasing power and political influence to improve the working conditions of the people that grow their food. By making public commitments to sourcing socially responsible food products and ensuring full supply chain transparency and traceability, the plant-based foods industry can help ensure their products meet the highest standards of social responsibility.

\subsection{Nutrition and human health implications of plant-based seafood}

The emergence of plant-based seafood presents an opportunity to harness technological and culinary innovations to develop products that can replicate and enhance not only the taste and texture of seafood, but also its nutritional attributes. Nutritionists have long recommended a diet rich in unprocessed, high-quality, nutrient-dense fruits and vegetables. While plant-based seafood producers are striving to develop products that reflect this ideal, the nutritional profiles of plant-based seafood products vary and are a function of both the process and the ingredients used to create specific products.

\subsubsection{Health and nutritional benefits}

$0 \quad$ Lean and nutrient rich protein source

Shifting from conventional seafood to plant-based seafood does not need to come at the expense of getting adequate amounts of protein. There is a wide variety of sources of vegetable protein including soy, quinoa, mushrooms, lentils, chickpeas, and legumes. For example, legumes including split peas, lentils, green soybeans as well as kidney, pinto, white, black, garbanzo, and lima beans are recognized as an excellent source of protein and provide nutrients like those found in seafood including iron and zinc. ${ }^{156}$ As such, the USDA recommends that Americans consume the equivalent of 1.5 cups of legumes each week. ${ }^{157}$

Likewise, seaweed, algae and micro-algae, which provide additional flavor and nutrition to many plant-based seafood products, can offer nutritional advantages. The nutrient density and seafood (umami) flavor of seaweed and algae support their application in plant-based seafood alternatives seeking to replicate the taste and texture of conventional seafood. Low in calories and sodium, seaweed can also contain high levels of fiber and protein and serve as a source of calcium, potassium, iron, iodine, and vitamins A, C, K, and B12. Many species of

\footnotetext{
152 World Bank Group. (n.d.) Employment in agriculture (\% of total employment) (modeled ILO estimate). Retrieved from https://data.worldbank.org/indicator/SL.AGR.EMPL.ZS. Accessed through Resource Watch, (January 2020). www.resourcewatch.org. 153 ibid.

154 United Nations News. (24 October 2018). Those who produce food are among world's hungriest-UN rights expert. https://news.un.org/en/story/2018/10/1023992

155 ibid.

156 U.S. Department of Health and Human Services and U.S. Department of Agriculture. (December 2015) 2015-2020 Dietary Guidelines for Americans. 8th Edition. http://health.gov/dietaryguidelines/2015/guidelines/.

157 ibid.
} 
seaweed are also rich in omega-3s, including the long-chain EPA and DHA found in fish oil, as well as the shorterchain alpha linolenic acid. ${ }^{158}$

While evidence is still emerging regarding the potential health benefits of seaweed, some studies suggest that seaweed may reduce the risk of breast cancer and cardio-vascular disease, benefit cholesterol levels, and have anti-inflammatory and antioxidant properties. ${ }^{159}$

\section{$0 \quad$ Low risk of PCB Exposure}

To discredit assertions by the plant-based industry promoting the nutritional attributes of plant-based seafood alternatives including the lack of PCBs, the National Fisheries Institute, a seafood industry trade organization, claims that most of the PCBs found in the American diet are derived from vegetables (20 percent) and not fish (9 percent). ${ }^{160}$ However, experts disagree noting that most people are exposed to PCBs by eating contaminated fish, meat, and dairy products as PCBs accumulate in the fatty tissue of animals. ${ }^{161}$ In reality, plants take up only small amounts of PCBs from the soil, so the concentration of PCBs in grazing animals and dairy products are generally lower than in fish. While dust contaminated with very low levels of PCBs may be found on the outer surfaces of fruits and vegetables, plant-based diets generally offer a lower risk of PCB exposure. ${ }^{162}$

\subsubsection{Health and nutritional risks}

o Risk of contaminant exposure

Both plants and seaweed can absorb environmental contaminants. Thus, if the water or soil in which these foods are grown are contaminated with substances such as mercury, lead, cadmium or other heavy metals, the seaweed or plant will likely contain those substances. In the case of seaweed, certain species may be at higher risk of containing dangerously high levels of iodine, mercury, and arsenic. ${ }^{163}$ A 2013 study in South Korea found that those who consumed a diet with moderate to high amounts of seaweed had high blood mercury levels compared with those who consumed low amounts of seaweed. ${ }^{164}$ As such, an understanding of the agricultural practices (e.g., fertilizer and pesticide applications) environmental conditions (e.g., proximity to polluting industries and run-off, etc.), and management controls in place where the plants and sea greens are produced is critical to mitigating the risk of contaminant exposure.

\section{$0 \quad$ Processed}

The processing of both terrestrial and marine plants into products that resemble conventional seafood is a strategic approach to shift consumption patterns away from animal-derived products and offer consumers a more diverse portfolio of options that can better align with their values around health, sustainability, and animal welfare. That said, plant-based food products are typically highly processed, which may have implications for the nutritional values of plant-based seafood alternatives. Indeed, many plant-based alternatives incorporate purified plant protein, such as pea and soy protein isolate and concentrate, rather than whole foods. ${ }^{165}$ The

\footnotetext{
${ }^{158}$ Bjerregaard, R. (n.d.) Seaweed Aquaculture for Food Security, Income Generation and Environmental Health in Tropical Developing Countries. World Bank Group. http://documents.worldbank.org/curated/en/947831469090666344/pdf/107147-WP-REVISED-Seaweed-Aquaculture-Web.pdf.

159 Yang, Y., Nam, S., Kong, G., \& Kim, M. (2010). A case-control study on seaweed consumption and the risk of breast cancer. British Journal of Nutrition, 103(9), 1345-1353. doi:10.1017/S0007114509993242

${ }^{160}$ National Fisheries Institute. (26 February 2019). Vegan Fish...Is Not Fish. https://www.aboutseafood.com/vegan-fish-is-not-fish/

${ }^{161}$ Agency for Toxic Substances and Disease Registry, U.S. Department of Health and Human Services. (2000) Public Health Statement for Polychlorinated Biphenyls (PCBs). https://www.atsdr.cdc.gov/PHS/PHS.asp?id=139\&tid=26

162 Illinois Department of Public Health. (n.d.) Polychlorinated Biphenyls (PCBs).

http://www.idph.state.il.us/cancer/factsheets/polychlorinatedbiphenyls.htm

${ }^{163}$ Holdt SL, Kraan S. (2011) Bioactive compounds in seaweed: functional food applications and legislation. J Appl Phycol. 2011;23:543-597.

164 Park, S. \& Lee, B.K. (2012). Strong Positive Associations Between Seafood, Vegetables, and Alcohol With Blood Mercury and Urinary Arsenic Levels in the Korean Adult Population. Archives of environmental contamination and toxicology. 64. 10.1007/s00244-012-9808-x.

${ }^{165}$ Hu, F.B., Otis, B.O., \& McCarthy, G., (2019). Can Plant-Based Meat Alternatives Be Part of a Healthy and Sustainable Diet? MS JAMA 322: $1547-1548$.
} 
processing ${ }^{166}$ of food can reduce the amount of natural nutrients present in the plant ingredients. ${ }^{167}{ }^{168}$ Table 6 outlines the percentage loss in vitamins and minerals resulting from different types of food processing compared with raw food.

In addition to a reduction of the important nutrients such as fiber, vitamins, minerals, and phytochemicals, 169 experts caution that many plant-based foods are higher in saturated fat compared with most minimally processed plant-based protein sources, such as beans and lentils. ${ }^{170}$ This may explain why studies have found that consuming diets high in ultra-processed food causes excess caloric intake and weight gain. ${ }^{171}$ Recognizing the stigma associated with processed foods and seeking to align their brands with more health-conscious consumers, some companies are focusing on developing whole food products with minimal processing. ${ }^{172}$

Table 6. Typical Maximum Nutrient Losses from Food Processing ${ }^{173}$

\begin{tabular}{|c|c|c|c|c|c|}
\hline \multicolumn{6}{|c|}{ Typical Maximum Nutrient Losses (as compared to raw food) } \\
\hline Vitamins & Freeze & Dry & Cook & Cook+Drain & Reheat \\
\hline Vitamin A & $5 \%$ & $50 \%$ & $25 \%$ & $35 \%$ & $10 \%$ \\
\hline $\begin{array}{l}\text { Retinol Activity } \\
\text { Equivalent }\end{array}$ & $5 \%$ & $50 \%$ & $25 \%$ & $35 \%$ & $10 \%$ \\
\hline Alpha Carotene & $5 \%$ & $50 \%$ & $25 \%$ & $35 \%$ & $10 \%$ \\
\hline Beta Carotene & $5 \%$ & $50 \%$ & $25 \%$ & $35 \%$ & $10 \%$ \\
\hline $\begin{array}{l}\text { Beta } \\
\text { Cryptoxanthin }\end{array}$ & $5 \%$ & $50 \%$ & $25 \%$ & $35 \%$ & $10 \%$ \\
\hline Lycopene & $5 \%$ & $50 \%$ & $25 \%$ & $35 \%$ & $10 \%$ \\
\hline Lutein+Zeaxanthin & $5 \%$ & $50 \%$ & $25 \%$ & $35 \%$ & $10 \%$ \\
\hline Vitamin C & $30 \%$ & $80 \%$ & $50 \%$ & $75 \%$ & $50 \%$ \\
\hline Thiamin & $5 \%$ & $30 \%$ & $55 \%$ & $70 \%$ & $40 \%$ \\
\hline Riboflavin & $0 \%$ & $10 \%$ & $25 \%$ & $45 \%$ & $5 \%$ \\
\hline Niacin & $0 \%$ & $10 \%$ & $40 \%$ & $55 \%$ & $5 \%$ \\
\hline Vitamin B6 & $0 \%$ & $10 \%$ & $50 \%$ & $65 \%$ & $45 \%$ \\
\hline Folate & $5 \%$ & $50 \%$ & $70 \%$ & $75 \%$ & $30 \%$ \\
\hline Food Folate & $5 \%$ & $50 \%$ & $70 \%$ & $75 \%$ & $30 \%$ \\
\hline Folic Acid & $5 \%$ & $50 \%$ & $70 \%$ & $75 \%$ & $30 \%$ \\
\hline Vitamin B12 & $0 \%$ & $0 \%$ & $45 \%$ & $50 \%$ & $45 \%$ \\
\hline Minerals & Freeze & Dry & Cook & Cook+Drain & Rehoat \\
\hline Calcium & $5 \%$ & $0 \%$ & $20 \%$ & $25 \%$ & $0 \%$ \\
\hline Iron & $0 \%$ & $0 \%$ & $35 \%$ & $40 \%$ & $0 \%$ \\
\hline Magnesium & $0 \%$ & $0 \%$ & $25 \%$ & $40 \%$ & $0 \%$ \\
\hline Phosphorus & $0 \%$ & $0 \%$ & $25 \%$ & $35 \%$ & $0 \%$ \\
\hline Potassium & $10 \%$ & $0 \%$ & $30 \%$ & $70 \%$ & $0 \%$ \\
\hline Sodium & $0 \%$ & $0 \%$ & $25 \%$ & $55 \%$ & $0 \%$ \\
\hline Zinc & $0 \%$ & $0 \%$ & $25 \%$ & $25 \%$ & $0 \%$ \\
\hline Copper & $10 \%$ & $0 \%$ & $40 \%$ & $45 \%$ & $0 \%$ \\
\hline
\end{tabular}

\footnotetext{
${ }^{166}$ Note: The U.S. Department of Agriculture (USDA) defines a processed food as any raw agricultural commodity subjected to washing, cleaning, milling, cutting, chopping, heating, pasteurizing, blanching, cooking, canning, freezing, drying, dehydrating, mixing, packaging, or other procedures that alter the food from its natural state. The food may include the addition of other ingredients such as preservatives, flavors, nutrients and other food additives or substances approved for use in food products, such as salt, sugars, and fats. In addition, the Institute of Food Technologists expands on the USDA's definition to include storing, filtering, fermenting, extracting, concentrating, microwaving, and packaging of raw product within their definition of processed food.

167 Hu, F.B., Otis, B.O., \& McCarthy, G., 1547-1548.

168 Weaver, C.M., Dwyer J., Fulgoni III V.L., King J.C., Leveille G.A., MacDonald R.S., Ordovas J., Schnakenberg D. (2014) Processed foods: contributions to nutrition. The American journal of clinical nutrition. 99(6):1525-42.

169 Hu, F.B., Otis, B.O., \& McCarthy, G., 1547-1548.

170 Lemonier, G. (n.d.) Great-Tasting Veggie Burgers Are Here, But Are They Any Healthier? Men's Journal. Accessed November 15, 2019.

https://www.mensjournal.com/food-drink/great-veggie-burgers-are-here-but-are-they-any-healthier-w449490/.

${ }^{171}$ Hall KD, A.A., Brychta R.et al. (8 May 2019). Ultra-processed diets cause excess calorie intake and weight gain: an inpatient randomized controlled trial of ad libitum food intake. Cell Metab. 30(1): 67-77.e3. doi:10.1016/j.cmet.

172 Mayle, T. Sea Ahead Bluetech Innovation. (22 August 2019). Will Plant-Based Seafood Products Prove to Be a Sustainable Alternative? https://seaahead.com/news/2019/8/19/how-ocean-hugger-foods-stimulates-sustainability-and-profitability-through-their-plant-based-alternatives-to-seafood 173 USDA Table of Nutrient Retention Factors Release 5 (2003)
} 
Despite the increasing variety of plant-based seafood ingredients, many products still rely on soy and wheat gluten for their protein base. For many consumers however, soy and/or wheat are allergens that can prompt a range of reactions from gastro-intestinal issues to swelling and hives to anaphylactic shock. Both soy and wheat are included on the FAO's list of the eight most significant food allergens (along with milk, eggs, fish, crustaceans, peanuts, and tree nuts).

In the U.S., three million people (approximately one percent of the U.S. population) have celiac disease, a hereditary autoimmune condition, while another 18 million individuals (six percent of the population) have a gluten sensitivity. Notably, the preference for gluten-free products extends beyond those with diagnosed gluten allergies or sensitivities. Gluten-free marketing efforts in recent years have 41 percent of Americans believing that a gluten-free diet is the healthier choice. ${ }^{174}$ Similarly, soy is also a common food allergen that can cause gastrointestinal discomfort, respiratory distress or skin reactions, and is found in about 0.3 percent of the general population. ${ }^{175}$

\subsection{Cell-Based Seafood}

Cell-based seafood (also referred to as in-vitro seafood, cultured seafood, cultivated seafood, cellular aquaculture, and synthetic seafood) sits at the intersection of biology and engineering and is viewed by some as a transformative biotechnology with the potential to feed the world without destroying it. It combines developments in biomedical engineering with modern aquaculture techniques and is projected to be more sustainable, safe, and humane than intensive fishing and aquaculture operations.

Unlike plant-based seafood, cell-based fish are real fish as they are produced from the muscle and fat cells of an actual fish (or invertebrate). As Lauran Madden, the Associate Director of Research with Blue Nalu describes it, cell-based seafood producers "extract each cell type from the species of interest and grow them in liquid media (amino acids, salts, vitamins, and fats) to increase the number of cells. ${ }^{176}$ In addition to the technical considerations, cell-based producers are working to develop seafood products that align with culinary and cultural demands and expectations, comply with regulatory requirements, and address sustainability concerns. ${ }^{177}$

While still in the research and development phase, proponents of cell-based seafood note that it offers the promise of becoming a more cost-effective and widely accessible protein option, at least within developed countries. They also point out that cell-based food production could represent new and profitable industry creating livelihood opportunities around the globe. However, more research is needed to develop the technology, reduce production costs, and understand the potential environmental, human health and socioeconomic impacts, reduce production costs of cell-based seafood products.

\subsection{Cell-based seafood market and industry trends}

While cell-based seafood is still in the research and development phase and lags behind its cell-based meat counterparts, investors and entrepreneurs alike are optimistic that seafood will follow the market projections

\footnotetext{
${ }_{174}$ Upton, J. (June 2015). Think You're Sensitive to Gluten? Think Again. U.S. News and World Report. https://health.usnews.com/health-news/blogs/eatrun/2015/06/11/think-youre-sensitive-to-gluten-think-again

${ }^{175}$ Katz, Y., Gutierrez-Castrellon, P., González, M.G.,; Rivas, R. Lee, B.W.; Alarcon, P. (15 January 2014). A Comprehensive Review of Sensitization and Allergy to Soy-Based Product. Clinical Reviews in Allergy and Immunology. 46 (3): 272- 281.

doi:10.1007/s12016-013-8404-9. ISSN 1080-0549. PMID 24425446.

176 Olayanju, J. (22 July 2019). Cell-Based Seafood: 4 Important Facts Everyone Should Know. Forbes.

https://www.forbes.com/sites/juliabolayanju/2019/07/22/cell-based-fish-4-important-facts-everyone-should-know/\#262e0088c97a

177 Rubio N, Datar I, Stachura D, Kaplan D and Krueger K (2019) Cell-Based Fish: A Novel Approach to Seafood Production and an Opportunity for Cellular Agriculture. Front. Sustain. Food Syst. 3:43. doi: 10.3389/fsufs.2019.00043

https://www.frontiersin.org/articles/10.3389/fsufs.2019.00043/full
} 
for the global cultured meat market, which is currently estimated to be valued at USD 214 million by 2025 and USD 593 million by 2032. ${ }^{178}$ Compared to other regions, the North American market for cell-based meat is projected to grow the fastest given the high level of investments in this space, the rate of innovation, and the increasing demand among consumers for alternative protein sources. ${ }^{179}$ To make cell-based seafood an accessible and affordable alternative to conventional seafood, the industry has several hurdles to overcome including improving consumer acceptance, securing regulatory approval, and addressing cost competition with the conventional seafood industry.

Leveling the playing field so that cell-based seafood can compete on equal footing with the conventional seafood industry will require economies of scale, as well as progressive policy reforms to eliminate unfair government subsidies and compel industry to internalize environmental externalities (e.g., costs associated with greenhouse gas emissions, water and energy use, land use).

Cost parity with conventional seafood will take time. Indeed, the first edible cell-based beef patty took two years and over USD 300,000 to produce in 2013. Since then, the costs have decreased as technology has improved, but the most optimistic estimates still put the cost of a cell-based burger at USD 10 if the technology can be scaled to an industrial level. ${ }^{180}$ Cell-based seafood faces the same cost conundrum, but the higher market price for certain conventional seafood products (e.g., salmon and tuna fillets) coupled with marketing strategies targeting higher end restaurants and retail establishments may help to minimize the sticker shock while socializing the concept of cell-based seafood until the production can be further refined and/or "upscaled" to reduce costs.

Plant- and cell-based seafood alternatives are also disadvantaged by the practice of government subsidies. As noted previously, harmful government subsidies continue to enable otherwise unprofitable and unsustainable fisheries around the globe. A 2009 study conducted by the Lenfest Ocean Program found that between 1996 and 2004 , the U.S. fishing industry received an average of USD 713 million per year in state and federal government subsidies. ${ }^{181}$ Researchers estimated that total value of subsidies equated to approximately one-fifth the value of the catch itself and was largely dominated by fuel subsidies ${ }^{182}$ thereby contributing to greenhouse gas emissions. U.S. government subsidies for the U.S. fishing industry can have the effect of encouraging less sustainable practices, artificially deflating prices, and putting the emerging cell-based sector at a competitive disadvantage.

As with any industry, the cost of inputs is an important variable in the commercialization of cell-based seafood. Whereas fuel is the primary input for wild-capture fisheries, cultured seafood relies on feed to fuel the growth of its product. Already, producers are exploring strategies to lower feed costs with different growth media configurations, improvements to cellular efficiency (the number of cells that can be grown per liter of media), and the ability to recycle the growth media. ${ }^{183}$ Blue Nalu, for example, just announced a partnership with Nutreco, a Dutch provider of aquafeed. Nutreco offers Blue Nalu an opportunity to accelerate research, development, and commercialization by bringing expertise in fish nutrition, raw materials, and ingredient procurement. Meanwhile, Nutreco benefits by diversifying its product portfolio and supporting a partnership that aligns with its own sustainability goals. ${ }^{184}$

\footnotetext{
${ }^{178}$ Research and Markets (September 2019). Cultured Meat Market by Source (Poultry, Beef, Seafood, Pork, and Duck), End-Use (Nuggets, Burgers, Meatballs, Sausages, Hot Dogs), and Region (North America, Europe, Asia Pacific, Middle East \& Africa, South America) - Global Forecast to 2032. https://www.researchandmarkets.com/reports/4844553/cultured-meat-market-by-source-poultry-beef\#pos-0

179 ibid.

180 Ireland, Tom. (23 May 2019). The artificial meat factor - the science of our synthetic supper. Science Focus.

${ }^{181}$ Sharp, R. and Sumaila, U.R.. (2009). Quantification of U.S. marine fisheries subsidies. North American Journal of Fisheries Management 29(1): 18-32.

182 ibid.

${ }^{183}$ Howell, M. (1 May 2019). Cell-based seafood and the future of food: part I. The Fish Site. https://thefishsite.com/articles/cell-based-seafood-and-thefuture-of-food-part-i

${ }^{184}$ Chase, C. (16 January 2020). BlueNalu, Nutreco enter strategic partnership. Seafood Source.

https://www.seafoodsource.com/news/aquaculture/bluenalu-nutreco-enter-strategic-partnership?
} 
Some fear that regulatory approval (e.g. in food safety, marketing, etc.) may be the biggest hurdle to commercializing cell-based seafood. While the industry is working closely with the FDA to develop appropriate food safety guidelines tailored to this new sector, other government interventions (both legal and legislative) could help clear the path for cell-based seafood or create more obstacles.

Generating consumer acceptance of cell-based seafood is a marketing challenge that is as much about the species demand as it is about nomenclature, accessibility, affordability, and taste. The industry is actively working to understand how best to position itself to communicate with and appeal to consumers. Currently, there are less than a dozen companies venturing into this space and each has its own vision and market niche in mind. Some companies are looking to sidestep competitive pushback from the U.S. domestic seafood industry by cultivating exotic and under-utilized fish species and localizing them to new geographies. Others are looking to differentiate themselves by targeting imported and/or overexploited species to provide a "more sustainable" alternative to popular seafood products. BlueNalu, for instance, is focusing on developing: mahi mahi, a popular species but heavily imported; red snapper, which is overfished and experiencing overfishing in the U.S.; and yellowtail. At the same time, they are working to develop the platform technology so they can create fresh and saltwater fish of any species with no genetic modification. Meanwhile, Finless Foods is developing Bluefin tuna, one of the most overexploited and expensive varieties of seafood, to redirect the market demand for wild caught Bluefin tuna and generate greater revenue from the start.

\subsection{Environmental costs and benefits of cell-based seafood}

At this early stage in the development of cell-based seafood, there remains a lot of uncertainty regarding its potential environmental costs and benefits. What limited research has been conducted has largely focused on cell-based meat production, but even so, most of the analyses are based on projected rather than actual impacts. As with any industry, the large-scale industrialization of cell-based seafood will inevitably involve plenty of sustainability challenges and trade-offs as the industry evolves.

\subsubsection{Biodiversity}

In addition to reducing pressure on wild populations, the development of cell-based seafood technology could potentially support the conservation of endangered, threatened, overfished, and otherwise vulnerable marine and aquatic species. In theory, the creation of cell-lines from these species could help reduce the economic and environmental pressures from fisheries, shift the demand for these species from wild-caught to cell-based, and make the illegal trade and fishing less profitable. The projected positive impacts of cell-based seafood rest on a series of assumptions that have yet to be tested. However, organizations like Environmental Market Solutions Lab at the University of California at Santa Barbara and the National Center for Ecological Analysis and Synthesis (NCEAS) are developing models to test those assumptions and identify the economic, ecological, social and political conditions under which innovations in cell-based seafood could drive a conservation benefit. ${ }^{185}$

\subsubsection{Land and habitat use}

A 2015 "anticipatory life-cycle analysis" of cell-based meat industry acknowledged that significant uncertainty remains, but suggested that preliminary findings indicate that cell-based meat production could use less land than livestock. ${ }^{186}$ At this stage, it is difficult to predict how much land would be required to enable the mass production of cell-based seafood. However, unlike terrestrial agriculture and many types of aquaculture, there may be less of a need for extensive habitat conversion to produce cell-based seafood as existing infrastructure

\footnotetext{
${ }^{185}$ Exploring the Conservation Impacts of Cell-Based Seafood (n.d.). https://ucsbcellbasedfish.weebly.com/research.html

${ }^{186}$ Mattick, C.S., Landis, A.E., Allenby, B.R., and Genovese, N.J. (2015) Anticipatory Life Cycle Analysis of In Vitro Biomass Cultivation for Cultured Meat Production in the United States. Environmental Science \& Technology 201549 (19), 11941-11949. DOI: 10.1021/acs.est.5b01614
} 
may be re-purposed and adapted to provide space for seafood cultivation facilities negating the need, in some circumstances, to convert undeveloped land. Compared with wild-capture fisheries and aquaculture operations, which frequently require separate facilities for processing and storage, cell-based seafood can be stored in the facility where it is grown. This may reduce the need for extensive land or sea-based infrastructure.

\subsubsection{Greenhouse gas emissions}

Given the nascent nature of cell-based seafood, there is limited research out there to support emission projections in this new sector. Estimates developed for the cell-based meat sector may be the closest analog, but those projections have been based on comparisons with animal agriculture. One study predicted that cellbased meat production would lead to 7 to 45 percent lower energy use and 78 percent to 96 percent lower greenhouse gas emissions than traditional livestock agriculture. ${ }^{187}$ Similar studies have yet to be conducted comparing conventional seafood production with cell-based seafood production, however given the carbon footprints of both wild-capture fisheries and aquaculture and the parallels between cellular technology for meat and seafood, it's foreseeable that cell-based seafood would also involve less energy use and greenhouse gas emissions than fisheries and aquaculture.

Furthermore, compared with cell-based meat production, cell-based seafood may be less energy intensive. Researchers and cell-based producers have observed that marine cell cultures may be more forgiving in terms of temperature, $\mathrm{pH}$, and oxygen requirements compared to mammalian cell cultures, which may have implications for energy use and cost in mass production. Whereas mammalian cells need to be maintained at a certain temperature, room temperature is sufficient for most fish cells. What's more, cell-based seafood production facilities can be established almost anywhere in the world, including inland regions. As such, local producers could cater to regional demands reducing transport times and distance and consequently GHG emissions. Whether this potential energy and emissions savings is offset by other more energy-intensive aspects of cellbased seafood production, including the increased amount of automation, remains to be seen.

\subsection{Socio-economic costs and benefits of cell-based seafood}

\subsubsection{Socio-economic benefits of cell-based seafood}

Environmentalists and economists alike argue that the diversification of our food system - just like diversification of investment portfolios - is an important risk mitigation strategy, particularly in this age of geopolitical uncertainty and climate change. While still several years away from full commercialization, some companies are contemplating the creation of food production facilities in different geographies - potentially with region-specific products. This could reduce the need for imported seafood while creating jobs and adding to the local economy.

From a food security perspective, cell-based seafood may also be a more efficient means of seafood production. Compared with aquaculture operations, which can take months to grow fish and shellfish to a harvestable size, it is estimated that cell-based seafood cultivation can take a matter of weeks before the product is ready for harvest. If cell-based seafood can be scaled effectively, this could enable more food production per unit of time and potentially help contribute to global food security by meeting the world's seafood demand more efficiently.

\subsubsection{Socio-economic costs of cell-based seafood}

If the production of cell-based seafood were scaled globally, wild-capture fisheries and aquaculture would undergo significant changes. Most companies in this space are not publicly suggesting that cell-based seafood

\footnotetext{
187 Tuomisto, H.L. and Joost Teixeira de Mattos, M. (2011) Environmental Impacts of Cultured Meat Production. Environmental Science \& Technology 201145 (14), 6117-6123. DOI: 10.1021/es200130u
} 
replace the conventional seafood sector. Rather, they are promoting cell-based seafood as an alternative that will help diversify the food system and provide consumers with more choices. Nevertheless, some investors and entrepreneurs predict that cell-based protein is poised to be a major disruptor to traditional meat and seafood industries that could reshape our food system in dramatic ways. To what extent cell-based seafood replaces industrial-scale fisheries and aquaculture operations or if it evolves into a niche product remains to be seen.

Given the technology-intensive nature of cell-based seafood production, there is an increased amount of automation in processing and production associated with contamination prevention, which could mean fewer opportunities for employment in this sector as compared with conventional seafood production and processing. Likewise, with the highly technical nature of cell-based seafood production, producers are already noting challenges hiring qualified staff with relevant experience. Whether finding qualified personnel continues to be a limiting factor to growth and expansion in the cell-based seafood sector remains to be seen. Creating a diverse, qualified, and global workforce to support this new industry will require training for workers of all skill levels.

Some advocates of cell-based food production caution that the technical nature of the industry could lead to privatization and consolidation of food production. To avoid that, organizations like New Harvest and The Good Food Institute are working to reduce barriers to entry by supporting more research, transparency, investments, and information sharing within the burgeoning sector.

\subsection{Nutrition and human health implications of cell-based seafood}

\subsubsection{Health and nutritional benefits}

o Nutritious and contaminant free

Since cell-based fish are molecularly identical to wild capture fish, the nutritional values attributed to many different types of seafood products are also the same. At the same time, some of the health risks (mercury, PCBs, plastics, antibiotics, etc.) associated with conventional seafood consumption can be eliminated in cellbased seafood given the controlled environment in which it is produced. Currently, cell feed is composed of all edible components (e.g., amino acids, salts, vitamins and fats), however in the future, the feed content could be adjusted to increase the amount of healthy fats and improve the nutritional profile of different species.

\section{o Clean and low risk of contamination}

Because cell-based seafood will be produced in a sterile environment, cell-based seafood producers maintain that the rates of foodborne illnesses and spoilage may be less than that of conventional seafood products ( $M$. Selden, personal communication, 26 December 2020). Like "other cell-based food processes such as yogurt (bacteria) or beer (yeast), the cells can be grown in large, pre-sterilized tanks. This ensures cleanliness of the cell-based products compared to the traditional products." ${ }^{188}$ Water or incoming nutrients are sterilized by heat or filtration and monitored for quality to ensure they are free of toxins, mercury, and micro plastics. Air filtration and negative pressure can also be used to prevent contaminants from entering sensitive areas. As with other food and biopharmaceutical facilities, much of the production process will be automated, which will help to limit the amount of human contact and further minimize the risk of contamination. ${ }^{189}$ What's more, the ability to create cell-based seafood production facilities nearly anywhere in the world means that producers can cater to local demand. Reducing transport time and exposure can also help to mitigate the risk of contamination and spoilage.

\footnotetext{
188 Olayanju, J. (22 July 2019). Cell-Based Seafood: 4 Important Facts Everyone Should Know. Forbes. https://www.forbes.com/sites/juliabolayanju/2019/07/22/cell-based-fish-4-important-facts-everyone-should-know/\#262e0088c97a 189 ibid.
} 


\subsubsection{Health and nutritional risks}

O Growth Media

One of the obstacles confronting cell-based seafood production is the need to develop serum-free growth media. Typically, media is made from animal (bovine) blood which is not approved for human consumption and offers the potential for disease growth and spread. Some cell-based seafood producers however note that the creation of serum-free media is a relatively easy problem to solve and its characterization as an obstacle is more of a red herring by critics.

\subsection{Governance Opportunities and Obstacles}

As the demand and interest in plant- and cell-based products accelerates, these producers are finding themselves navigating new and uncertain political and regulatory terrain. From jurisdictional uncertainties and labeling restrictions to unfair government subsidies and a lack of federal funding, plant and cell-based seafood companies are struggling to level the playing field, gain regulatory clarity, and establish themselves in an increasingly competitive landscape.

To represent the sectors' interests and respond to emerging regulatory, legislative and public relations issues influencing their industries, plant-based producers formed the Plant Based Food Association in 2016 and, more recently, five companies working to develop cell-based meat, poultry and seafood formed the Alliance for Meat, Poultry \& Seafood Innovation (AMPS Innovation).

\subsection{Federal agency jurisdiction}

While the U.S. FDA will continue to regulate the production and labeling of plant-based foods, agency oversight of cell-based foods was more uncertain until recently. It wasn't until March 2019 that the FDA and the United States Department of Agriculture's (USDA) Food Safety and Inspection Service announced an agreement to share regulatory oversight of cell-based foods. FDA and USDA will work together to oversee the process of developing and commercializing meat- and poultry-derived cell-cultured products and enforcing regulations focused on food safety and labeling of the products. The FDA will oversee cell collection, cell banks, and cell growth and differentiation, while the USDA will oversee cell harvest/food production and labeling. ${ }^{190}$ In the case of cell-based seafood however, the FDA will maintain full oversight, but FDA and USDA will develop joint principles for product labeling. Therefore, cell-based seafood will likely be subject to the same labeling standards as cell-based meat and poultry. While the agencies have agreed that no additional legislation is needed at this juncture to move forward with shared jurisdiction, they have yet to provide additional guidance or publish proposed regulations offering further details on the management of cell-based food production.

\subsection{Federal and state labeling laws}

Federal agency jurisdiction and regulatory guidance, however, is not the only governance obstacle facing these emerging industries. A flurry of federal and state labeling laws designed to limit competition and disadvantage plant- and cell-based food companies have emerged.

At the federal level, a recently introduced bill, H.R 4881 and a parallel bill in the Senate, S. 306, both entitled "The Real Marketing Edible Artificials Truthfully (MEAT) Act of 2019", aim to ensure that consumers can make

\footnotetext{
${ }_{190}$ Crews, J. (8 March 2019). Government agencies to share oversight of cell-based food products. Food Business News. https://www.foodbusinessnews.net/articles/13447-government-agencies-to-share-oversight-of-cell-based-food-products
} 
informed decisions in choosing between meat products, such as beef and imitation meat products. The Real MEAT Act would amend the Federal Food, Drug, \& Cosmetic Act (FDCA ${ }^{191}$ ), which mandates that all labeling must be truthful and not misleading, to require that "any imitation meat food product, beef, or beef product shall be deemed to be misbranded unless its label bears, in type of uniform size and prominence, the word 'imitation' immediately before or after the name of the food and a statement that clearly indicates the product is not derived from or does not contain meat." ${ }^{192}$ The bill also defines "beef" or "beef product" as "any product containing edible meat tissue harvested in whole form from domesticated Bos indicus or Bos taurus cattle" effectively excluding plant and cell-based meat products. ${ }^{193}$ Proponents contend that the bill is about transparency and protecting consumers from misleading and deceptive marketing practices. Critics, on the other hand, argue that the proposed legislation, which is supported by the National Cattlemen's Beef Association and the U.S. Cattlemen's Association, is protectionist and serves only to disadvantage alternative protein producers. While the scope of the bill does not extend to seafood, it is indicative of the threat that conventional animalbased protein producers perceive alternative protein producers posing to their industry and the strategies they are pursuing to secure their place in the market.

Meanwhile, upwards of 45 bills to censor plant- and cell-based products have been introduced in 26 states and 17 have passed in 14 states including Mississippi, Missouri, Oklahoma, Montana, South Carolina, North Dakota, South Dakota and Arkansas. While only a few reference plant- and/or cell-based seafood (Missouri, Oklahoma, Louisiana, Georgia, and Wisconsin), these protectionist laws may present further obstacles to the commercialization and scaling of plant- and cell-based seafood products in the U.S. Proponents of plant- and cell-based food have filed lawsuits in Missouri, Arkansas and Mississippi, claiming, among other things, that these restrictive labeling laws violate first amendment protections for commercial speech. While the cases in Missouri and Arkansas are still pending, the case brought in Mississippi was dropped by the plaintiffs after the Mississippi Department of Agriculture withdrew the proposed labeling regulation and replaced it with regulations that would allow plant-based producers to continue to use common plant-derived food labels they believe consumers understand.

In addition to protectionist labeling laws, a bill introduced in Washington State would also make it a crime to sell lab-grown meat and would bar state funds from being used for research in the field. While increasing transparency and accountability in food labeling is a laudable goal, opponents of such legislation are concerned that the intent and the effect of these laws is to limit competition by disadvantaging plant- and cell-based companies.

\subsection{Government funding and support}

There are a variety of legislative, regulatory and policy vehicles that support the advancement of domestic fisheries and aquaculture research, trade and production. As noted previously, the U.S. fishing industry receives an estimated USD 713 million per year in state and federal government subsidies. ${ }^{194}$ While some of these are harmful subsidies (e.g., fuel subsidies) and expenditures to address the direct and indirect consequences of mismanagement and overexploitation of coastal and marine resources from fisheries and aquaculture (e.g., vessel buybacks and species recovery and habitat restoration programs), others are more benign or beneficial. For example, the federal Farm Bill includes several provisions that subsidize and incentivize research into and the advancement of U.S. aquaculture production, including the Aquaculture Assistance Program which provides competitive grants to support aquaculture research and assistance. Similarly, the Saltonstall-Kennedy (S-K) federal grants program provides over USD 1 million annually to companies, NGOs and others that are focused on the promotion, development, and marketing of U.S. seafood and/or the science or technology that

\footnotetext{
${ }^{191} 21$ U.S.C. $\$ 343(a)$

192 The Real Marketing Edible Artificials Truthfully (MEAT) Act of 2019, HR 4881, 116 $6^{\text {th }}$ Cong. (2019)

193 ibid.

${ }^{194}$ Sharp, R. and Sumaila, U.R.,18-32.
} 
promotes sustainable U.S. seafood production and capture. ${ }^{195}$ Whether they are harmful or helpful, these subsidies create an uneven playing field and offer the conventional seafood industry a competitive advantage over their plant- and cell-based seafood counterparts who currently lack comparable levels of government funding support.

The most recent U.S. Dietary Guidelines (2017) promotes the health benefits of seafood and recommends that the general population consume at least eight ounces per week of a variety of seafood. However, the Dietary Guidelines Advisory Committee and the UN-FAO concurred that aquaculture production will have to rapidly increase substantially to meet the recommendation that Americans eat at least eight ounces of seafood per week. This suggests that cell-based seafood, which has the same nutritional profiles (or some would argue, better) and potentially fewer contaminants as compared with their conventional seafood counterparts, may play a role in filling that gap so long as the legal, governance and funding infrastructure exists to advance research and development into seafood alternatives.

\subsection{Research \& Resource Needs and Opportunities}

With any new and emerging field, there are inevitably a lot of unknowns, uncertainties and kinks that need to be worked to scale growth and understand the associated costs and benefits. The following is a non-exhaustive list of some of the gaps in knowledge and potential areas of inquiry for plant- and/or cell-based seafood alternatives. While the answers to some of these challenges are being actively pursued by various producers, academics and NGOs, more research capacity and resources are needed to understand, advance, and ensure cost competiveness and transparency in these emerging sectors.

As discussed above, conventional (wild-caught and farm-raised) and alternative (plant- and cell-based) seafood have both positive and negative environmental, socio-economic, and human-health impacts, however there are still large gaps in our current understanding of these shifting impacts. Sustainability in consumption patterns and lifestyle choices are increasingly on the minds of the public and decision-makers. For concerned consumers and conservation organizations, like the Wildlife Conservation Society, to embrace and promote these products, a better understanding of the environmental and socio-economic implications of alternative seafood is needed. These nascent industries are still in the early phases of their growth and development and such, there is an opportunity for they and other stakeholders to get ahead of the curve and invest in the research and analyses needed to address outstanding questions.

As the demand for protein for an expanding human population grows, it may be less of a question of whether alternative seafood is more sustainable than conventional seafood in terms (we will likely need both), but how to minimize the adverse environmental and socio-economic impacts associated with both conventional and alternative seafood while meeting the health and nutritional needs of consumers wherever they are.

Below we outline some of the questions and data gaps that have been laid evident throughout this white paper, expert interviews and the Wildlife Conservation Society's March 2020 workshop, particularly with regards to environmental sustainability. These questions may benefit from a concerted and coordinated effort from government, academic, and non-profit researchers. We recognize that assessing these impacts is highly dependent on the species, ingredients, location, scale, and production methods associated with different plantand cell-based seafood products. This variability means that a single life-cycle analysis (LCA) cannot be done for the entire plant- and/or cell-based seafood categories, and perhaps not even for sub-categories (e.g., "plantbased tuna") where there may be a diversity of product ingredients, sourcing geographies and agricultural practices employed. Still, the areas of inquiry outlined below are intended to provide guidance for the kinds of sustainability analyses consumers and others are beginning to expect.

${ }^{195}$ NOAA Fisheries. Saltonstall-Kennedy Grant Program. (n.d.) https://www.fisheries.noaa.gov/grant/saltonstall-kennedy-grant-program (Visited March 17, 2020) 
Although not discussed in this white paper, the burgeoning plant-based and cell-based meat industries utilize some of the same agricultural ingredients (e.g., soy and pea protein) and/or agricultural practices as many plantbased seafood products. Industry-sponsored LCAs, which look at look at variables such as of land, water, and energy use, as well as their carbon emissions, have been developed for products like the Impossible Burger ${ }^{196}$ and Beyond Burger. ${ }^{197}$ Likewise, a limited number of anticipatory LCAs have been conducted for cellular meats to project the likely impacts of cell-based meat production, which is still in the research and development phase. ${ }^{198}, 199$ While some of the questions raised below, such as impacts on biodiversity, have not been adequately assessed for meat alternatives, these LCAs may be heuristic and offer a source of relevant data to apply to both plant- and cell-based seafood assessments.

The following highlights potential lines of inquiry that are common to both plant- and cell-based seafood as well those that are specific to each product sector. As these industries develop and our knowledge evolves, so too will research needs and opportunities to coordinate and collaborate across disciplines and sectors.

\subsection{Plant-based and cell-based seafood}

- $\quad$ Environmental Sustainability

$0 \quad$ Product-specific environmental life-cycle assessments conducted by independent third parties to enable better comparisons between different plant-based seafood and wild-capture fisheries and aquaculture products as well as terrestrial protein sources. How do different plant-based and cell-based seafood products compare with their conventional counterparts in terms of land, energy and water use, greenhouse gas emissions, waste, eutrophication, and biodiversity and habitat impacts among other things?

$0 \quad$ An assessment of which seafood species are likely to accrue the greatest conservation benefits (e.g., reduction in fishing pressure) if there are plantbased and/or cell-based analogs developed.

- $\quad$ Socio-Economic

o Estimates of the amount of plant-based and/or cell-based seafood needed to help meet the projected trends in demand for protein, with or without a decline in traditional seafood availability.

$0 \quad$ Area- and species-specific studies that evaluate the direct and indirect potential socio-economic impacts (e.g., job and revenue loss, food access, etc.) that shifts in demand from conventional seafood to plant-based seafood may create. What regions, fisheries, and aquaculture operations are most vulnerable to increasing competition with plant-based and/or cell-based seafood?

$0 \quad$ Area- and species-specific studies that evaluate the potential socio-economic opportunities (e.g., alternative livelihood development, food security, etc.) that

\footnotetext{
196 “Environmental Life Cycle Analysis: Impossible Burger 2.0." Impossible Foods. Accessed December 3, 2019. https://impossiblefoods.com/mission/lcaupdate-2019/.

197 Heller, M. and Keoleian, G. (2018) Beyond Meat's Beyond Burger Life Cycle Assessment: A Detailed Comparison between a Plant-based and an AnimalBased Protein Source. Center for Sustainable Systems University of Michigan, September 14, 2018. http://css.umich.edu/sites/default/files/publication/CSS18-10.pdf

198 Mattick, C.S., Landis, A.E., Allenby, B.R., and Genovese, N.J. (2015) Anticipatory Life Cycle Analysis of In Vitro Biomass Cultivation for Cultured Meat Production in the United States. Environmental Science \& Technology 201549 (19), 11941-11949. DOI: 10.1021/acs.est.5b01614

${ }^{199}$ Scharf, A., Breitmayer, E. and Carus. (2019) Review and gap-analysis of LCA-studies of cultured meat. Study for the Good Food Institute. https://www.gfi.org/images/uploads/2020/01/Cultivated-Meat-LCA-Report-2019-0709.pdf
} 
shifts in demand from conventional seafood to plant-based and/or cell-based seafood may create.

$0 \quad$ An examination of to whom the potential benefits of alternative seafood is most likely to accrue. Will plant-based seafood products be accessible only to more affluent consumers in developed countries? How can the potential benefits associated with plant-based and/or cell-based production and consumption be equitably distributed?

$0 \quad$ Considering the growing awareness of human rights abuses in the seafood supply chain, assessments are needed of labor practices, worker safety, health, and human rights associated with the production of many plant-based seafood ingredients.

$0 \quad$ An examination of the relationship between government subsidies and product development/food production. What role do national and sub-national government subsidies play in the U.S. and beyond to support and/or hinder the diversification of food systems and the development of new food products and sectors?

- $\quad$ Consumer Attitudes and Behavior

o Region and/or country-specific evaluations of consumer attitudes, including if and how people can be motivated to shift or diversify their food preferences and consumption patterns to include plant-based and/or cell-based seafood alternatives in their diets.

o An examination of whether an increase in the consumption of plant- and/or cellbased seafood alternatives is likely to correlate with a demand for, or reduction in, the consumption of conventional seafood (and other animal-based proteins). ${ }^{200}$

$0 \quad$ An assessment of whether an expansion in alternative seafood consumption will reduce pressure on and/or contribute to the recovery of traditional seafood species.

\subsection{Plant-based seafood}

- $\quad$ Environmental Sustainability

o Food systems-level research to understand whether and to what extent a shift from conventional seafood (and/or terrestrial animal agriculture) to more plantbased seafood production will increase the pressure on terrestrial food systems.

$0 \quad$ An exploration of the potential synergies and opportunities to support sustainable and regenerative agriculture ${ }^{201}$ with producers of plant-based seafood ingredients and other agricultural producers.

o Development of a comprehensive and comparative model for plant-based seafood LCAs that reflects the full suite of relevant environmental impacts and can be tailored to individual products. This may include building on and aligning the methodology with the LCA's being developed for plant-based meat production.

\footnotetext{
${ }^{200}$ Hu, F.B., Otis, B.O., \& McCarthy, G., 1547-1548.

${ }^{201}$ Note: "Regenerative Agriculture" is a system of farming principles and practices that increases biodiversity, enriches soils, improves watersheds, and enhances ecosystem services. Regenerative Agriculture aims to capture carbon in soil and aboveground biomass, reversing current global trends of atmospheric accumulation. At the same time, it offers increased yields, resilience to climate instability, and higher health and vitality for farming and ranching communities. The system draws from decades of scientific and applied research by the global communities of organic farming, agroecology, Holistic Management, and agroforestry, (http://www.regenerativeagriculturedefinition.com)
} 
$0 \quad$ There are a limited number of primary ingredient crops currently used in the production of plant-based seafood (e.g., peas, soy, wheat, seaweed, algae oil, etc.). An assessment of the environmental impacts of scaling the production of different primary ingredients (per kg protein) is needed to understand the likely impacts of projected growth in the plant-based seafood industry.

0 Land use: An assessment of whether an increase in plant-based seafood production will lead to an increase in global agricultural land use. Where will geographic expansion likely occur and be concentrated? To what extent can existing rangeland and farms be converted to produce key plant-based seafood ingredients? Will uncultivated land/habitat need to be converted to meet increasing production demands and, if so, what habitats would be most at risk (e.g., rainforests, prairies, etc.)?

o Biodiversity: An assessment of impact on the wildlife and habitats in regions that undergo expansion in cultivation to meet plant-based seafood needs? What species are most vulnerable to agricultural expansion, and will this put already vulnerable species or habitat at further risk?

o Water use: An assessment of the added demands (from both cultivation and processing) on global and regional freshwater resources as plant-based seafood production scales. Are there plant-based seafood ingredients that are less water intensive than others? Relative to water scarcity, what geographic areas are most appropriate and hospitable to the plant-based seafood ingredient production? What are the potential water consumption benefits of shifting from farm-raised to plant-based seafood?

o Pollution/eutrophication: Assessment and comparison of the impacts to local and regional water quality from plant-based seafood production and aquaculture including nutrient loading, pesticides, and pharmaceutical applications.

$0 \quad$ Energy and GHG emissions: Assessment of plant-based seafood species energy and carbon footprint, particularly in comparison to their wild-caught and/or farm-raised counterparts.

o Animal feed: An evaluation of whether and to what extent plant-based seafood might serve as animal feed replacing the need for wild fish in aquaculture and/or livestock production?

o Waste: Identification of opportunities to reduce waste in all operations, including product spoilage, packaging, water, and energy and to apply circular economy approaches.

- Health and Nutrition

o To address questions about the health effects of plant-based seafood, rigorously designed, independently funded studies are needed, including short-term intervention trials to compare the effects of the plant-based seafood products with conventional seafood products and minimally processed plant protein sources on cardio metabolic risk and other factors such as the microbiome. ${ }^{202}$

o Studies that examine how the consumption of plant-based seafood alternatives influence individuals' overall diet quality, caloric intake, nutrient status, and body weight. ${ }^{203}$

\footnotetext{
${ }^{202}$ Hu, F.B., Otis, B.O., \& McCarthy, G., 1547-1548.

203 ibid.
} 
- Technical

o An understanding of the physical, molecular and nutritional parameters that define high-quality seafood from commercially relevant species to enable plantbased seafood producers to create products that meet the taste, texture and health expectation of consumers. ${ }^{204}, 205$

\subsection{Cell-based seafood}

- $\quad$ Environmental Sustainability

o Models that forecast the implications and explore potential impact-mitigating solutions of scaling up cell-based seafood production and the impacts on natural resources and environmental sustainability.

o Land use: What is the footprint of a cell-based seafood cultivation facility and the projected needs for scaling up? How does this compare with cell-based meat facilities? To what extent can existing infrastructure be repurposed for cell-based seafood production? What are the agricultural demands for feedstock/growth media production?

o Biodiversity: Analyses that build on the models coming out the UCSB and NCEAS research ${ }^{206}$ to further elucidate the potential of cellular aquaculture to stimulate the recovery of wild-caught species populations, while accounting for the potential impacts to terrestrial species (animal and plant) where these facilities operate.

o Water use: Analyses of the potential demand on global and regional freshwater resources as cell-based seafood production expands and scales. How waterintensive is cell-based seafood production? Does the cultivation of some species demand more freshwater resources than others? What role does recycled and/or grey water play in cell-based seafood production? Relative to water scarcity, what geographic areas are most appropriate and hospitable to the production of cell-based seafood? How does the amount of water used to produce specific cell-based seafood species compare with their wild-caught and/or farmed analogs?

o Pollution/eutrophication: An anticipatory assessment of the impacts to local and regional water quality from cell-based seafood production including nutrient loading, pesticides, and pharmaceutical applications. How do the pollution and eutrophication levels associated the cellular production of certain seafood species compare with their farm-raised, plant-based and/or wild-caught counterparts?

o $\quad$ Energy and GHG emissions: Anticipatory analyses for energy and carbon footprint from cell-based seafood, from facility construction through product transport. How does the energy use and GHG emissions associated cell-based seafood compare with that of cell-based meat, aquaculture, plant-based seafood and wild-caught fisheries?

\footnotetext{
${ }^{204}$ McHugh, T. (1 October 2019). How Plant-Based Meat Seafood Are Processed. IFT Food Technology Magazine. https://www.ift.org/news-andpublications/food-technology-magazine/issues/2019/october/columns/processing-how-plant-based-meat-and-seafood-are-processed ${ }^{205}$ The Good Food Institute developing a detailed characterization of the seafood products that plant- and cell- based seafood are trying to emulate to enable a better understanding of the molecular and structural signatures that define consumer experiences like taste, aroma, and texture as well as nutritional, aesthetic, and processing qualities. (See https://drive.google.com/viewerng/viewer?url=https://www.gfi.org/files/sci-tech/seafood/proposal2-seafood.pdf)

${ }^{206}$ Note: See Exploring the Conservation Impacts of Cell-Based Seafood (n.d.). https://ucsbcellbasedfish.weebly.com/research.html
} 
Can Plant- and Cell-Based Seafood Improve human and Planetary Health?

- $\quad$ Consumer Attitudes

o An exploration of consumer attitudes and why and how people can be motivated to shift or diversify their food preferences and consumption patterns to include cell-based seafood alternatives.

o An examination of whether an increase in the consumption of cell-based seafood alternatives may correlate with a reduction in the consumption of conventional seafood (and other animal-based proteins) ${ }^{207}$ and reduce pressure on and/or contribute to the recovery of commercial species.

- Health and Nutrition

o An exploration of whether different cell-based products (resulting from different cell lines or growth serums, packaging, etc.) have different health impacts.

o Research to examine the relative health impacts of specific cell-based seafood species as compared with their wild fisheries and aquaculture counterparts.

- Technical

o Research to generate a greater understanding of fish and invertebrate muscle cell and tissue cultivation.

o $\quad$ Research into and the development of cell lines for different commercially relevant seafood species.

- A publicly available resource to access to information and research regarding species cell lines and protocols and reduce barriers to entry into the field. ${ }^{208}$

o $\quad$ Further investigations into serum-free media formulations that are optimized for fish cell culture.

o Research and development into bioreactor designs that are tuned to the needs of fish cells for large scale production.

o Research into and development of tissue scaffolding to enable threedimensional, structured tissue formation.

\subsection{Conclusion}

Sustainability is a journey and not an end-point, and the more we learn and innovate, the more our notions of seafood sustainability evolve and expand. Whereas sustainability in the context of seafood was once narrowly construed as whether a specific target species was overfished or not, our collective vision for sustainability is expanding to include issues such as biodiversity, ecosystem health, carbon footprint, social equity, and animal welfare. Plant- and cell-based seafood alternatives challenge us to look even further outside the traditional "sustainability" box and explore how these novel products compare with traditional fisheries and aquaculture, what role they play in the broader food system, and how they align with changing consumer values and the growing demand for sustainable, healthy and ethical food. Whether plant- and cell-based seafood represent major disruptors to our food system or niche products remains to be seen, but what is clear is that thoughtful diversification of the global food system is needed to mitigate risk and feed a growing population. Advancing workable solutions will require a commitment to multi-sectoral collaboration, information-sharing, capacitybuilding, funding, as well as a transparent and equitable governance framework that levels the playing field and incentivizes innovation and a transition towards a food system that is healthy, sustainable, ethical, and socially responsible.

\footnotetext{
${ }^{207}$ Hu, F.B., Otis, B.O., \& McCarthy, G., 1547-1548.

${ }^{208}$ The Good Food Institute is developing a cell-line repository to respond to the lack of publicly available relevant seafood cell lines and protocols. (See https://drive.google.com/viewerng/viewer?url=https://www.gfi.org/files/sci-tech/seafood/proposal-1-seafood.pdf)
} 
Appendix: Workshop Agenda

\section{New York Aquarium \\ A Wildlife Conservation Society Park}

EXPloring the Costs AND Benefits of SeAfood Alternatives

Can Plant- and Cell-Based Seafood Improve Human and Planetary Health?

MARCH 2, 2020

AgENDA

\section{$9: 30$}

$10: 00$

$10: 30$

11:50

$11: 45$

12:00

\section{Registration \& Coffee}

\section{Welcome \& Introduction}

Jon Dohlin (Vice President and Director, Wildlife Conservation Society's New York Aquarium) Merry Camhi (Director, New York Seascape Program, Wildlife Conservation Society's New York Aquarium)

Meghan Jeans (Consultant and Workshop Coordinator)

\section{Seafood Sustainability: An evolving concept}

Our notions of seafood sustainability continue to evolve and expand as we learn and innovate. Chef Bun Lai will set the stage for our exploration of plant-and cell-based seafood by sharing his sustainability journey and highlighting the role that chefs and restaurants play in advancing awareness, expanding consumer palates and influencing consumption patterns.

Bun Lai (Chef/Owner, Miya's Sushi)

\section{The Evolution of Plant-Based Seafood}

An exploration of the evolution of plant-based seafood and the environmental, socio-economic and human health costs and benefits of this growing industry.

Monica Van Cleve-Talbert (President, Van Cleve Seafood)

Christopher Kerr (CEO, Good Catch)

David Benzaquen (Co-Founder and CEO, Ocean Hugger Foods)

\section{Coffee Break}

\section{The New Frontier of Cell-Based Seafood}

An examination of the origins and mechanics of cell-based seafood, its future role as a global food source, and the potential environmental, socio-economic and human health costs and benefits of this new industry.

Lauran Madden (Assistant Director, Research and Product Development, Blue Nalu) Heather Lahr (Project Manager, University of California at Santa Barbara) Isha Datar (Executive Director, New Harvest) 
12:45

$1: 30$

2:15

3:00

$3: 15$

4:00

$5: 00$

$5: 15$

Lunch

Room in the Sandbox: Can plant- and cell-based seafood coexist with conventional seafood? Panelists will share perspectives on whether and how plant and cell-based seafood alternatives compete with and/or complement conventional seafood and agricultural industries.

Jan Tharp (President \& CEO, Bumble Bee Foods)

Elise Gilchrist (Communications Director, Dock to Dish)

Sian Morgan (Fisheries \& Markets Director, Waitt Institute)

Monica Van Cleve-Talbert (President, Van Cleve Seafood)

Leveling the Playing Field: Legal and political obstacles to mainstreaming plant- and cell-based seafood

From state and federal labeling laws to government subsidies and U.S. Dietary Guidelines, experts will outline some of the legal and political hurdles confronting plant and cell-based seafood.

Elizabeth Derbes (Assistant Director of Regulatory Affairs, The Good Food Institute) Laurie Beyranevand (Director, Vermont Law School's Center for Agriculture and Food Systems)

\section{Coffee Break}

Mind the Gap: Investigating information needs and opportunities to strengthen our knowledge and understanding of seafood alternatives

Panelists will highlight the types of research, investments and initiatives that are needed to advance plant and cell-based seafood and our understanding of the environmental, human health, and socio-economic impacts of these new and evolving industries.

Jennifer Lamy (Sustainable Seafood Initiative Manager, The Good Food Institute) Christopher Kerr (Chief Investment Officer, New Crop Capital)

Isha Datar (Executive Director, New Harvest)

Michaela Clemence (Executive Director, Environmental Market Solutions Lab at the University of California at Santa Barbara)

Understanding the drivers of consumer behavior and shaping consumer demand Participants will learn about new survey results regarding consumer preferences as it relates to plant and cell-based seafood. Working in small groups, participants will also explore our individual and collective understanding of consumer behavior and demand and what that means for influencing the future of healthy, humane, sustainable, and socially responsible seafood production and consumption.

Arlin Wasserman (Managing Director, Changing Tastes) - Unable to attend

\section{Conclusion \& Wrap-Up}

Reception

Join us for an evening of networking, cocktails and hors d'oeuvres including samples of plantbased seafood products provided by Ocean Hugger Foods, Good Catch, and Van Cleve Seafood. 